\title{
Epidemiological features and the neuropathological manifestations of canine distemper virus-induced infections in Brazil: a review
}

\author{
Aspectos epidemiológicos e manifestações neuropatológicas \\ associadas à infecção pelo vírus da cinomose canina no Brasil: \\ uma revisão
}

\author{
Selwyn Arlington Headley ${ }^{1 *}$; Alexandre Mendes Amude ${ }^{2}$; Alice Fernandes Alfieri ${ }^{3}$; \\ Ana Paula F. R. L. Bracarense ${ }^{3}$; Amauri Alcindo Alfieri ${ }^{3}$
}

\begin{abstract}
This review provides a critical review of current epidemiological trends of canine distemper virus (CDV) and syndromes related to canine distemper encephalitis (CDE) with specific reference to the situation in Brazil. Epidemiological data relative to susceptible animal populations, prevalence, seasonal occurrence, and age-related patterns associated with CDV are discussed. The participation of mongrel dogs in maintaining CDV within rural and semi-urban canine populations and their importance in the epidemiology of canine distemper is highlighted. The economic impact of treating the clinical manifestations associated with CDV-induced infections in Brazil is estimated. Additionally, neurological and neuropathological manifestations of CDV in Brazil are discussed, and a novel manifestation of CDE is proposed.
\end{abstract}

Key words: Dog, canine distemper, epidemiology, neuropathology

\section{Resumo}

Esse manuscrito apresenta uma revisão crítica das tendências epidemiológicas associadas a cinomose canina $(\mathrm{CDV})$ e às síndromes relacionadas à encefalite por cinomose com referência específica à situação no Brasil. Os dados epidemiológicos relativos às populações de animais suscetíveis, prevalência, sazonalidade e os padrões relacionados à idade foram discutidos. Também é enfocada nessa revisão a participação de cães de rua na manutenção do CDV nas populações caninas nas áreas rurais e nas regiões semiurbanas e a sua importância na epidemiologia da cinomose. Foi ainda estimado o impacto econômico relacionado ao tratamento das manifestações clínicas associadas à cinomose no Brasil. Adicionalmente, as manifestações neurológicas e neuropatológicas da cinomose são discutidas e uma manifestação neuropatológica inédita da infecção é sugerida.

Palavras-chave: Cão, cinomose canina, epidemiologia, neuropatologia

\footnotetext{
1 Pesquisador, Laboratory of Animal Virology, Department of Veterinary Preventative Medicine, Universidade Estadual de Londrina, P.O. Box 6001, Rodovia Celso Garcia Cid, PR 445 Km 380, Paraná, Brasil. E-mail: selwyn.headley@uel.br

2 Prof., Universidade de Cuiabá, UNIC, Mato Grosso, MS, Brasil. E-mail: amamude@hotmail.com

3 Profs., Universidade Estadual de Londrina, UEL, Londrina, PR, Brasil.E-mail: aalfieri@uel.br; anapaula@uel.br; alfieri@uel.br ${ }^{*}$ Author for correspondence
} 


\section{Introduction}

Historical data has suggested that the first valid description of canine distemper (CD) might have occurred in South America and not Europe (BLANCOU, 2004), because CD was probably observed as a highly contagious disease of dogs since 1746 in Peru (HOWELL, 1965; BLANCOU, 2004). After the distemper epizootics in South America, CD was then imported to Europe in 1760 (BLANCOU, 2004). Distemper then probably disseminated across the European continent beginning with Spain and England in 1760, Italy and Ireland in 1764, and then Russia in 1770 (BLANCOU, 2004). It is reported that 900 dogs in Madrid died in one day during 1763 from CD (BLANCOU, 2004). In 1767, a large number of dogs died from CD in Louisiana, USA, but it remained obscure if the dissemination occurred via contamination of dogs originating from Europe or South America (BLANCOU, 2004). In 1870, CD was described as the scourge of the canine race since it attacked dogs of all breeds and ages in the United Kingdom; healthier animals were more severely infected, mongrels were less affected, and corneal ulceration was described (McBRIDGE, 1870). In 1890, 90\% of affected dogs from several British municipalities died from $\mathrm{CD}$, having clinical manifestations of anorexia, fever, dryness of the nostrils, purulent oronasal discharge, diarrhea, purulent bronchopneumonia associated with a bacterial agent observed microscopically (MILLAIS, 1890).

The virus-induced etiology of $\mathrm{CD}$ was proposed by the French veterinarian Henri Carré in 1905; but the first classical description of the clinical signs was attributed to Edward Jenner in 1908 (APPEL, 1987a; MACLACHLAN; DUBOVI, 2011). However, the viral induced theory was contested by several early investigators who proposed a bacterium, Haemophilus bronchisepticus, as the etiologic agent, since this pathogen was observed within the respiratory system of live dogs and those necropsied with manifestations of CD during outbreaks of canine distemper virus (CDV) infection (GLEDHILL,
1953). The viral theory was not accepted until the results of the excellent experimental studies of 1926 by Dunkin and Laidlaw realized in ferrets were known in which six strains of CDV were described (GLEDHILL，1953; HOWELL， 1965). Dunkin and Laidlaw studied CD thoroughly in ferrets; the disease in ferrets was transmissible to dogs, and vice versa, and they concluded that both animals were infected by the same disease (GLEDHILL, 1953). $\mathrm{CD}$ as described by Dunkin and Laidlaw was an acute, infectious, febrile disease with an incubation period of four days, that was characterized by coryza, conjunctivitis, a diphasic elevation in body temperature, severe gastrointestinal alterations, discrete respiratory symptoms, but with infrequent observations of neurological manifestations of disease (GLEDHILL, 1953). However, between 1940 and 1950 the problem of plurality of the virus arose, caused predominantly by the emergence of the encephalitic syndrome, which was not completely described by Laidlaw and Dunkin (HOWELL, 1965). A new distemper syndrome, termed hard pad, was described by Rubarth in 1947, which differed from conventional $\mathrm{CD}$ due to the development of hyperkeratosis of the footpads and the frequent manifestations of encephalitis (GLEDHILL, 1953).

$\mathrm{CD}$ was known to produce elevated mortality in dogs and other susceptible carnivores worldwide (APPEL, 1987a), but it's occurrence in dogs is now considered rare and well controlled in many developed countries due to vaccination (MACLACHLAN; DUBOVI, 2011). However, in Brazil, CD is still the principal cause of mortality of dogs in some urban populations (HEADLEY; GRAÇA, 2000; FIGHERA et al., 2008) and there are increasing descriptions of infections occurring in non-conventional hosts (MEGID et al., 2009; HÜBNER et al., 2010), which might, if continues, cause the loss of endangered wildlife species. Dogs and non-canine hosts can produce clinical manifestations that result with life threatening disease affecting the respiratory, gastrointestinal, cutaneous, and/or nervous system. This dire situation 
makes the understanding of the epidemiological trends associated with CDV of fundamental importance for the implementation of adequate control and prophylactic measures. This review presents a critical review of the epidemiological findings and the neuropathological manifestations of CDV with specific references to the disease as it occurs in Brazil.

\section{Etiology and viral properties}

CDV is a member of the genus Morbillivirus, family Paramyxoviridae (LAMB; KOLAKOFSKY, 2001; MACLACHLAN; DUBOVI, 2011). CDV is antigenically similar to Rinderpest virus, phocine distemper virus, equine morbillivirus, cetacean morbillivirus, and pest des petit ruminants virus (QUINN et al., 2004; MACLACHLAN; DUBOVI, 2011). The manifestations of canine distemper encephalitis (CDE) are directly related to the strain of virus, the age and the immune status of the affected animal, and the neuroanatomic location affected (SUMMERS; GREISEN; APPEL, 1984; MACLACHLAN; DUBOVI, 2011). Due to the histopathological similarities of some chronic manifestations of CDE with multiple sclerosis and subacute sclerosing panencephalitis of humans (ADAMS et al., 1975; KOESTNER, 1975), distemper has been proposed as a model to study these neurological diseases.

CDV is a pleomorphic 150-250 nm diameter virion, with a single negative-stranded RNA that is enclosed in a helically symmetrical nucelocapsid (GREENE; APPEL, 2006; MACLACHLAN; DUBOVI, 2011). The virion proteins of CDV include three nucleocapsid proteins: an RNAbinding protein $(\mathrm{N})$ previously referred to as nucleocapsid protein (NP), a phosphoprotein (P), and a polymerase protein (L); and three membrane proteins: a matrix protein $(\mathrm{M})$; one fusion $(\mathrm{F})$, and an attachment hemagglutinin protein $(\mathrm{H})$ (LAMB; KOLAKOFSKY, 2001; MACLACHLAN; DUBOVI, 2011).
The $\mathrm{H}$ protein is fundamental for infection, since it recognizes compatible ligands on the surface of the host cell (MACLACHLAN; DUBOVI, 2011), and activates the $\mathrm{F}$ protein by tissues-specific proteases resulting in infection (McCARTHY; SHAW; GOODMAN, 2007). There is approximately $10 \%$ variation in the amino acid sequences of the $H$ protein, with biological effects on the virus-host reactions (KAPIL et al., 2008), and since it is one of the most variable morbillivirus proteins (PARDO; JOHNSON; KLEIBOEKER, 2005), has been extensively used to evaluate phylogenetic relationships of CDV lineages worldwide (PARDO; JOHNSON; KLEIBOEKER, 2005; McCARTHY; SHAW; GOODMAN, 2007; KAPIL et al., 2008; WOMA et al., 2010). Further, an adequate immune response by the host to this hemagglutinin protein might prevent infection (MARTELLA; ELIA; BUONAVOGLIA, 2008). The nucleocapsid (NP is associated with including encapsidation of the genome RNA into a template for RNA synthesis, with the P-L polymerase during transcription and replication, and interacts with the $\mathrm{M}$ protein during virus assembly into the affected host (LAMB; KOLAKOFSKY, 2001).

\section{Epidemiology of canine distemper virus- induced infections}

Susceptible animal populations, phylogenetic relationships, and prevalence

Canine distemper occurs worldwide and CDV has known to have crossed the original species barrier with infections occurring in members of the Canidae, Procyonidae, Mustelidae, Hyaenidae, Mustelidae, Procyonidae, Ursidae, Viverridae, and Felidae families (SUMMERS; APPEL, 1994; OSTERHAUS et al., 1995). Most terrestrial carnivores are considered susceptible to natural infections by CDV (APPEL, 1987a). A list of animals know to have been naturally and experimentally infected by CDV is given in Table 1. 
Table 1. Animals susceptible to infection by canine distemper virus ${ }^{1}$.

\begin{tabular}{|c|c|c|}
\hline \multirow{2}{*}{ FAMILY } & \multicolumn{2}{|l|}{ TYPE OF INFECTION } \\
\hline & Natural & Experimental \\
\hline Canidae & Dog, raccoon dog, dingo, fox, coyote, jackal, wolf & Dog, ferret \\
\hline Mustelidae & $\begin{array}{l}\text { Weasel, ferret, polecat, mink, skunk, badger, marten, otter, stoat, } \\
\text { wolverine, grison }\end{array}$ & Mink \\
\hline Felidae & Lion, leopard, cheetah, tiger, puma, jaguar, lynx, cat & Cat \\
\hline Viverridae & Masked palm civet, binturong, linsang, fossa & \\
\hline Ailuridae & Lesser panda & \\
\hline Suidae & Pig, peccary & Pig \\
\hline Procyonidae & Coati, kinkajou, racoon, bassariscus & \\
\hline Muridae & & Mouse, rat \\
\hline Cricetidae & & Hamster \\
\hline Ursidae & Bear, giant panda & \\
\hline Herpestidae & Mongoose, meerkat & \\
\hline Miscellaneous & Nonhuman primate, man? & Nonhuman primate \\
\hline
\end{tabular}

${ }^{1}$ Adapted from: Summers, B.A.; Appel, M.J.G. Aspects of canine distemper virus and measles virus encephalomyelitis. Neuropath. Appl. Neurobiol., v. 20, p. 525-534, 1994. Osterhaus et al., Morbillivirus infections of aquatic mammals: newly identified members of the genus. Vet. Microbiol.. v. 44, p. 219-227, 1995.

Source: Elaboration of the authors.

Phylogenetic analyses based on the $\mathrm{H}$ gene of CDV have demonstrated that there are seven distinct lineages circulating worldwide: Asia-1, Asia-2, America-1, America-2, Artic-like, European wildlife, and Europe (McCARTHY; SHAW; GOODMAN, 2007), with a new strain been recently identified in South Africa, termed lineage Africa (WOMA et al., 2010), and a distinct genotype might be occurring in Alpine wildlife (MONNE et al., 2011). However, probably due to inclusion criteria, isolates from Brazil were not included in these analyses. Nevertheless, there are four complete nucleotide sequences of the $\mathrm{H}$ gene from dogs diagnosed with $\mathrm{CD}$ from Londrina/PR deposited in GenBank based on the studies initiated by Negrão et al. (2006). Consequently, these sequences served as a base to create a phylogenetic tree (Fig. 1) based on strains of the CDV H gene deposited in GenBank that represented different geographical locations so that the phylogenetic relationship can be compared.
The previously described eight lineages of CDV (McCARTHY; SHAW; GOODMAN, 2007; WOMA et al., 2010) were clearly characterized when the strains were compared. The strains of CDV from Brazil seemed to form a distinct cluster, but one strain (EU098102) was distant from the others, suggesting that there might be two strains of CDV circulating within northern Paraná. Further, the Brazilian strains were more closely related to those from Europe but more distinct from strains circulating in the USA. This phylogenetic relationship suggests that the strains circulating in Brazil either represent a distinct lineage of CDV or might be part of the presently known European lineage of CDV. However, additional strains based on the $\mathrm{H}$ gene of CDV from different geographical regions of Brazil are needed and a more detailed phylogenetic investigation is required to confirm these findings, which nonetheless, are encouraging. 
Figure 1. Phylogenetic tree demonstrating the relationship of strains of canine distemper virus based on the $\mathrm{H}$ protein gene. The tree was constructed by the Neighbor-Joining method using 1000 bootstraps replicates. The GenBank accession numbers, the animal/strain, and country of origin are indicated. PDV (phocine distemper virus) was used as the out group. Evolutionary analyses distances were computed by using the Kimura 2-parameter method with the MEGA-5 software (TAMURA et al., 2007).

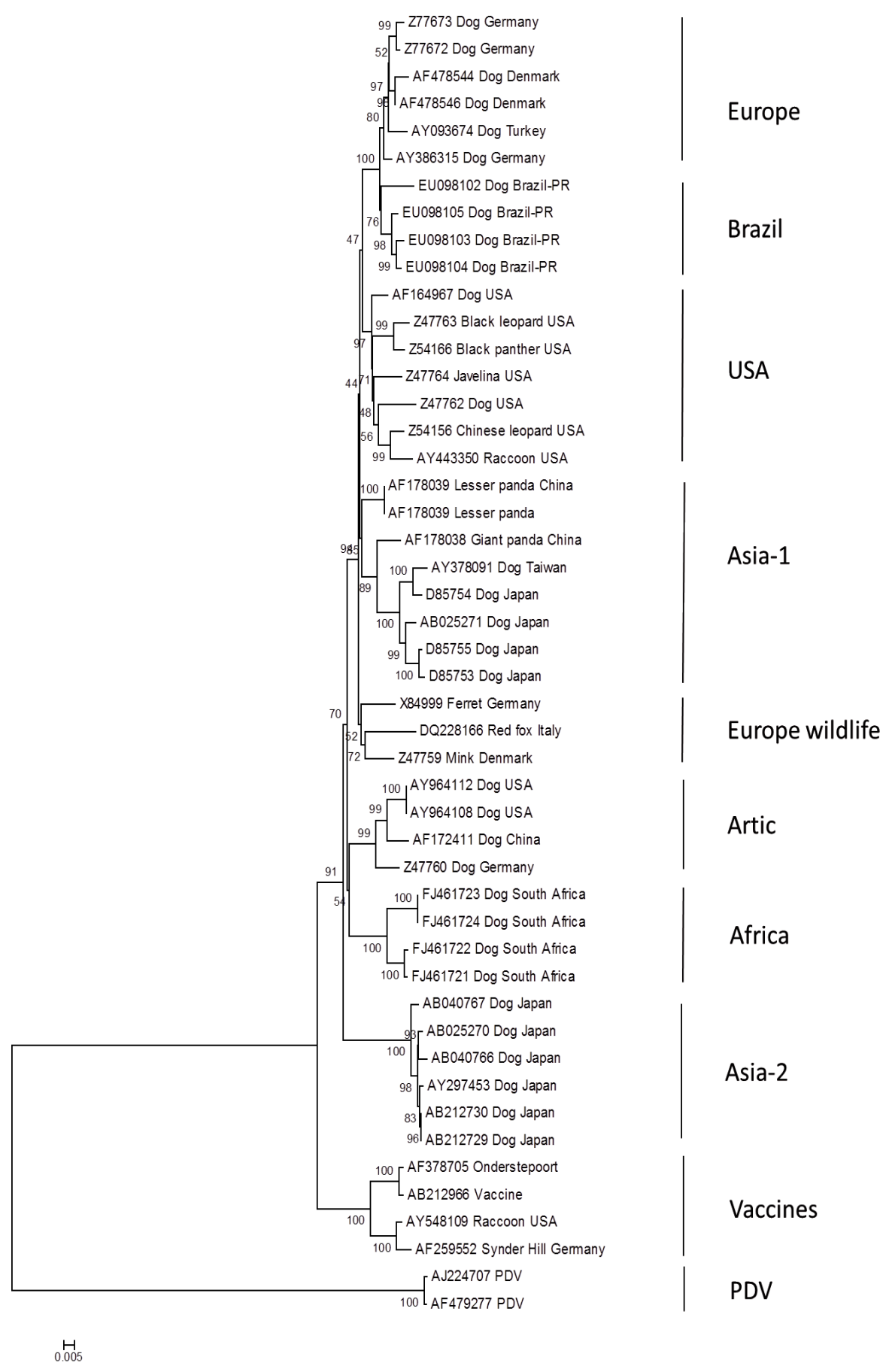

Source: Elaboration of the authors. 
Since there are more strains/isolates of the CDV N gene from Brazil deposited in GenBank, the phylogenetic relationship of CDV strains from different geographical based on the $\mathrm{N}$ gene is shown in Figure 2A. Strains from Brazil originated from the states of São Paulo and Paraná, and were grouped into two clusters (Fig. 2B). One of these contained only Brazilian strains and the other was mixed with strains from North America and Europe; suggesting that there are probably two strains of CDV circulating in Brazil (CASTILHO et al., 2007), and also in northern Paraná. However, both groups seemed to have evolved from European strains of CDV (Fig. 2B); one strain (AY38625) derived from the Onderstepoort vaccine, was grouped with other vaccine strains (Fig. 2B). The strains from Mexico formed a distinct cluster, and are considered as genetic variants of CDV (SIMON-MARTÍNEZ et al., 2008). Moreover, additional isolates of CDV from different geographical regions of Brazil are required so that a comprehensive holistic epidemiological understanding can be obtained. Nevertheless, when the two trees are compared, the phylogenetic relationship seemed better organized with the CDV $\mathrm{H}$ relative to the $\mathrm{N}$ gene.

In Brazil, epidemiological/prevalence studies have suggested that $\mathrm{CD}$ is endemic in urban canine populations, with indices of $6.1 \%$ in Belo Horizonte/MG based on clinical cases (GOUVEIA; MAGALHÃES; RIBEIRO, 1987). Retrospective studies using archival records of dogs submitted for routine necropsy have demonstrated CDV prevalence indices of $7.1 \%$ in Porto Alegre/RS (SONNE et al., 2009), with $11.7 \%$ (HEADLEY; GRAÇA, 2000), 12\% (SILVA et al., 2007) and $12.4 \%$ (FIGHERA et al., 2008) occurring in the city of Santa Maria/RS. Alternatively, seroprevalence surveys have demonstrated indices of $27.3 \%$ in Santa Maria/RS (DEZENGRINI; WEIBLEN; FLORES, 2007), 30\% in Belém/PA (GUEDES et al., 2010), and $58.3 \%$ in Pelotas/RS (HASS et al., 2008). This comparatively elevated prevalence indices of live dogs demonstrating positive seroreactivity to CDV in several Brazilian cities relative to those submitted for necropsy at Regional Reference
Institutions, might suggest that the actual incidence of $\mathrm{CDV}$ is more elevated than that described in retrospective studies. Further, the infectious indices (27\%) observed by seroprevalence (DEZENGRINI; WEIBLEN; FLORES, 2007) relative to those described in retrospective studies (11.7-12.4\%) in Santa Maria/RS (HEADLEY; GRAÇA, 2000; FIGHERA et al., 2008) might be true manifestations of the pathogenesis of CD, where approximately half the number of susceptible dogs who have been in contact with CDV are likely to develop an adequate immune response recovering from infection without apparent manifestation of disease, while part of the other half might succumb to the virus resulting in clinical disease and mortality (GORHAM, 1966; APPEL 1987a; GREENE; APPEL, 2006).

The first descriptions of CDV-induced lesions in autochthonous Brazilian wildlife probably occurred in the Municipal Zoo of Taboão da Serra/SP and were diagnosed in manned wolves, Chrysocyon brachyurus, greater Grisons, Galictis vittata, and the crab-eating fox, Cerdocyon thous (REGO et al., 1997). Since that initial report, there have not been documented descriptions of CDV-induced disease in Brazilian wildlife until the recent studies affecting members of the Canidae and Felidae families (MEGID et al., 2009; HÜBNER et al., 2010). Members including the crab-eating, Cerdocyon thous (MEGID et al., 2009; HÜBNER et al., 2010), hoary, Lycalopex vetulus (MEGID et al., 2010), and the pampas fox, Pseudalopex gymnocercus (HÜBNER et al., 2010), as well as the jaguar, Panthera leo, and the puma, Puma concolor (NAVA et al., 2008) have been reported as infected by CDV. However, seroepidemiological surveys realized in the region of the Serra do Cipó National Park, MG (CURI et al., 2010) and the Amazon city of Salvaterra, Marajó Island, PA (COURTENAY; QUINNELL; CHALMERS, 2001) did not detect the presence of CDV in wild canids. Nevertheless, $66 \%$ (46/70) of dogs native to the Serra do Cipó National Park (CURI et al., 2010) and 9\% (2/23) of their counterparts residing in Salvaterra (COURTENAY; QUINNELL; CHALMERS, 2001) demonstrated seroreactivity to circulating antibodies of CDV. 
Figure 2 A. Phylogenetic tree demonstrating the relationship of strains of canine distemper virus based on the $\mathrm{N}$ protein gene. The tree was constructed by the Neighbor-Joining method using 1000 bootstraps replicates. Evolutionary analyses distances were computed by using the Kimura 2-parameter method with the MEGA-5 software (TAMURA et al., 2007). The GenBank accession numbers and the continent with country of origin are indicated.

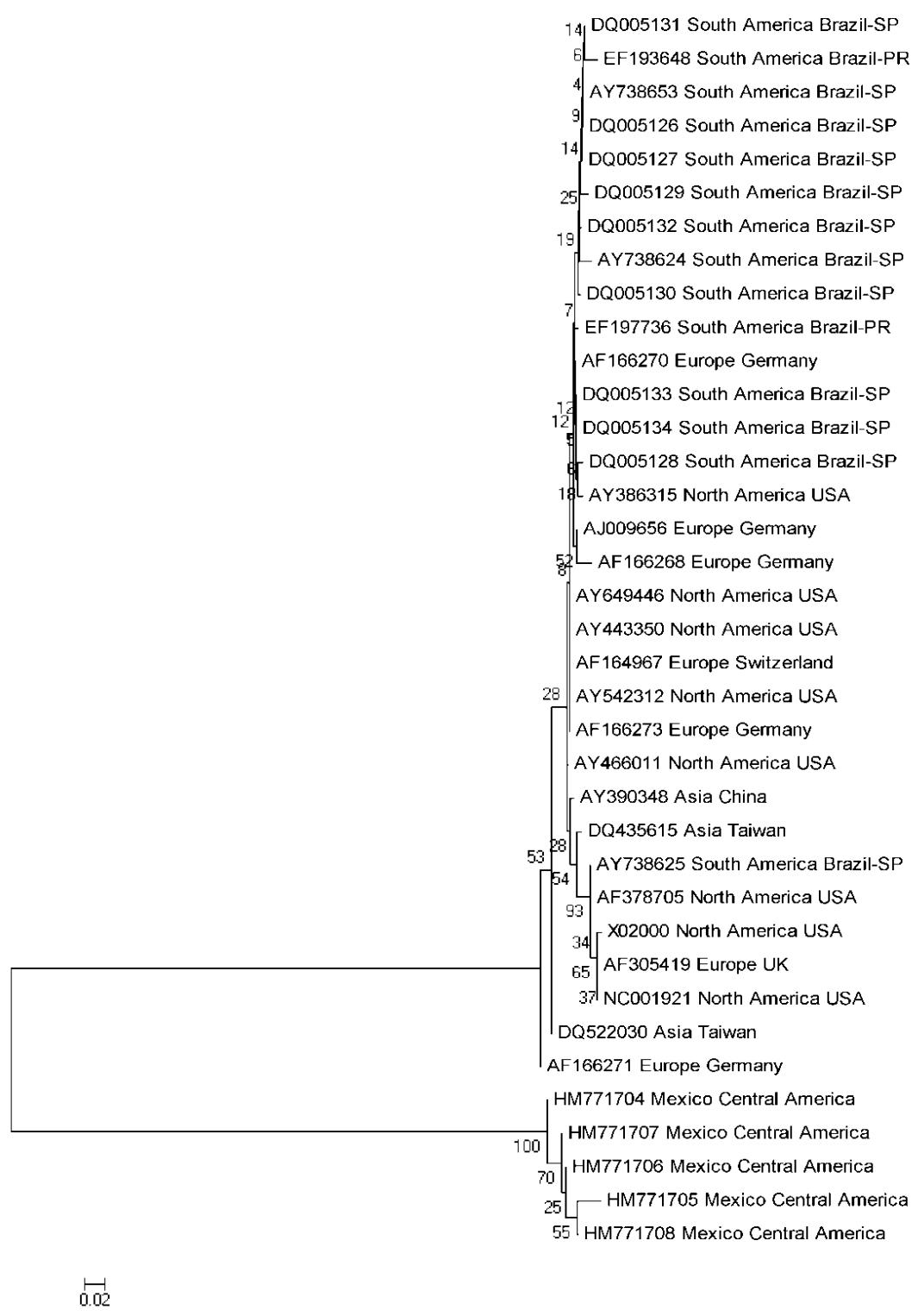

Source: Elaboration of the authors. 
Figure 2 B. Phylogenetic tree demonstrating the relationship of strains of canine distemper virus based on the $\mathrm{N}$ protein gene. This tree was constructed by the Neighbor-Joining method using 1000 bootstraps replicates, and was derived from Fig. 2 A to clearly demonstrate the evolutionary relationships of CDV isolates from Brazil. Evolutionary analyses distances were computed by using the Kimura 2-parameter method with the MEGA-5 software (TAMURA et al., 2007). The GenBank accession numbers and the continent with country of origin are indicated.

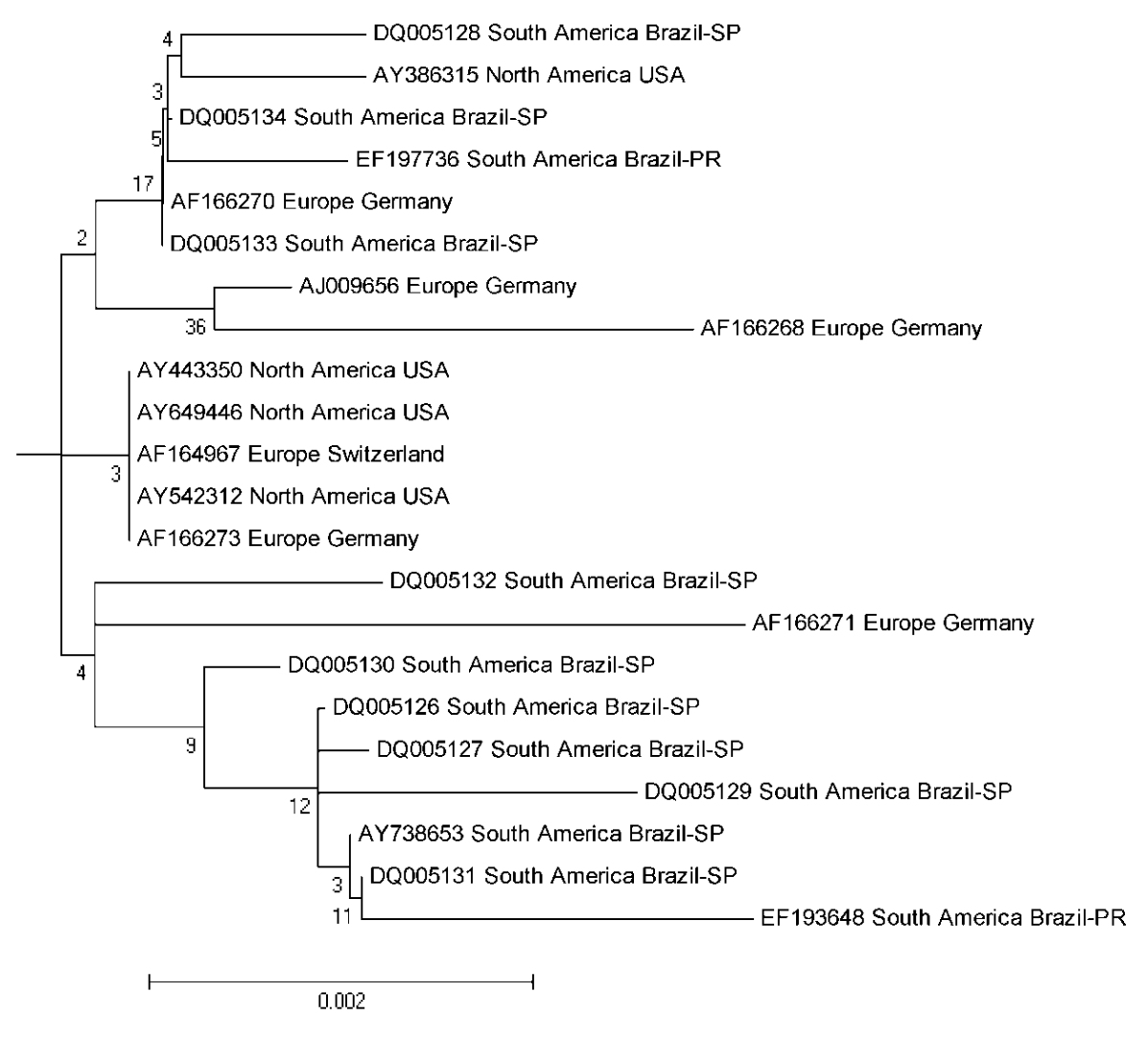

Source: Elaboration of the authors.

In most cases, where wildlife species have been infected by CDV in Brazil (NAVA et al., 2008; MEGID et al., 2009; 2010; HÜBNER et al., 2010), the spill-over effect due to spontaneous contact between infected dogs and susceptible animals has been incriminated as the cause of viral dissemination. The spill-over effect is characterized as the transmission of infectious agents from reservoir animal populations (more frequently domesticated species) to sympatric wildlife species (i.e., animals occupying the same or overlapping geographic areas without interbreeding) frequently results in emerging infectious diseases (EID) which can be fatal to the new host and threaten endangered species (DASZAK; CUNNINGHAM; HYATT, 2000). In the USA, CDV is endemic in raccoons (Procyon lotor), and these animals are considered as the most likely host to serve as a reservoir for CDV by which susceptible dogs and wildlife can become infected due to their interaction with raccoons in urban and semirural areas (KAPIL et al., 2008). Raccoons were incriminated as the source of infection in an outbreak of CDV in California, USA that resulted in the death of 17 large felids (APPEL et al., 1994). In Europe, martens (Martes spp.) are considered as possible intermediate wildlife 
reservoirs of CDV (MYERS et al., 1997; PHILIPPA et al., 2008), and were attributed as sources of infection that resulted in the death of 19 large felids in Switzerland (MYERS et al., 1997). These animals live in close proximity with humans and are likely to become contaminated by CDV-infected dogs (PHILIPPA et al., 2008). The scavenging habit of rural dogs or mongrels facilitates the ingestion of contaminated remains of dead raccoons left aimlessly along roadways and already infected with CDV (KAPIL et al., 2008), thereby serving as a vector to disseminate the disease to canine hosts that were not adequately vaccinated.

It can be argued that more molecular-based epidemiological studies must be done in Brazil in an attempt to identify the wildlife species that can serve as an alternative host and thereby disseminate CDV to susceptible animal populations, since there are still comparatively few reports of infections in native wildlife in Brazil relative to other countries. Alternatively, the epidemiological situation in Brazil might be completely different from that of North America or Europe, whereby there is no need for a wildlife species to disseminate CDV between infected and susceptible animal populations, which might explain the relatively few cases of distemper in uncommon hosts in Brazil. Nevertheless, the importance of CDV in urban and rural populations cannot be underscored, and it must be highlighted that $\mathrm{CD}$ has been classified as class 3 EID (i.e., a recognized infectious agent, affecting an emerging, new or increasing range of hosts, within a known geographical location) within the continental USA and Africa, since CDV endangers a wide host of carnivores, might be related to the extinction of the African wild dog and populations of black-footed ferrets, and threatens the survival of the Ethiopian wolf (DASZAK; CUNNINGHAM; HYATT, 2000). In Europe, CDV might be threatening the existence of the European mink, Mustela lutreola (PHILIPPA et al., 2008), and the Iberian lynx, Lynx pardinus (MELI et al., 2010).

\section{The importance of mongrel dogs}

In cases of CDV infections described in urban cities affecting dogs (HEADLEY; GRAÇA, 2000; GUEDES et al., 2010) or in forested areas with disease in wildlife (NAVA et al., 2008; MEGID et al., 2009; 2010; HÜBNER et al., 2010) in Brazil mongrel dogs are frequently associated with viral dissemination. Further, epidemiological data have demonstrated that mongrels represented the largest populations (54\%) of dogs infected with CDV in Santa Maria/RS (HEADLEY; GRAÇA, 2000 ), contributed to $44 \%$ of CDV-induced cases diagnosed in Porto Alegre/RS (SONNE et al., 2009), and $30 \%$ of all dogs with CDV from Belém/PA (GUEDES et al., 2010). Elevated indices of CDV infections in Brazilian mongrels are directly related to their lifestyle. Mongrels are more likely to roam the streets in semi urban and rural districts, have unknown vaccination status, are more susceptible to infections than their purebred counterparts, are more likely to have sporadic contacts with wildlife species and susceptible dogs in rural areas, have scavenging habits that are comparable to racoons, and might be the likely candidate to serve as reservoirs of CDV in Brazil. Further, in Brazil purebred dogs are more rigorously vaccinated against CDV than their mongrel counterparts, and epidemiological data has suggested that purebred dogs were not as frequently infected by CDV relative to mongrels (HEADLEY; GRAÇA, 2000). Although purebred dogs are infected by distemper, dolichocephalic breeds seem more susceptible to CDV than their brachycephalic counterparts (GORHAM, 1966; HEADLEY; GRAÇA, 2000).

In Finland, where the incidence of distemper is relatively low with no reported cases since the 19941995 outbreak (EK-KOMMONEN et al., 1997), the most recent cases of CDV infection were attributed to contact between susceptible pups and a roaming dog from Russia (HEADLEY; SUKURA, 2009) and Estonia (HEADLEY et al., 2009b); in the latter case, the dog also developed concomitant Tyzzer's disease and intestinal coccidiosis (HEADLEY et al., 
2009b). Additionally, the roaming habit of mongrels was associated with contamination by Dioctophyma renale in dogs from Londrina/PR (NAKAGAWA et al., 2007), concomitant infections of CDV, Toxoplasma gondii, and ehrlichiosis in dogs from Botucatu/SP (MORETTI et al., 2006), dual infections of CDV and T. gondii also in Botucatu/ SP (MORETTI et al., 2002), secondary Bordetella bronchiseptica purulent bronchopneumonia in two pups (HEADLEY et al., 1999), and in five cases of Nocardia asteroides infection in Sudan (FAWI; TAG EL DIN; EL-SANOUSI, 1971). A seroepidemiological survey realized in Pelotas/RS demonstrated that $68 \%$ of dogs positive for CDV had access to the street and $58 \%$ of all positive dogs were mongrels (HASS et al., 2008). The spillover effect as occurred in the USA (DASZAK; CUNNINGHAM; HYATT, 2000), was attributed to the dissemination of canine parvovirus, canine adenovirus, and canine coronavirus infections between infected mongrels and susceptible wild canids native to the Serra do Cipó National Park/MG (CURI et al., 2010), and to CDV-induced disease in large felids residing in State Parks of Mato Grosso do Sul (NAVA et al., 2008). Therefore, the large amount of mongrels that are easily encountered in several rural and semi-urban cities of Brazil would serve not only as reservoirs and distributors of CDV, but for other infectious disease agents, thereby excluding the necessity of having a wildlife species serving as an intermediate host for CDV in Brazil, as is described in North America (KAPIL et al., 2008) and Europe (MEYERS et al., 1997; PHILIPPA et al., 2008). Free roaming domestic dogs were also incriminated as being responsible for the spillover effect of CDV to black-backed jackals (Canis mesomelas) in Namibia, Africa (GOWTAGESEQUEIRA et al., 2009), to the Serengeti wildlife epidemic in Tanzania (CLEAVELAND et al., 2000), and possibly to the Iberian lynxes, whose population is estimated to be approximately 200 individuals (MELI et al., 2010).

Epidemiological data suggest that in Brazil CDV might be equally endemic in dogs from different age groups (discussed below). This then raises the obvious question as to why dogs in Brazil, although protected by attenuated vaccine, frequently demonstrate elevated indices of infection by CDV. Although vaccination failures could be partially associated with this phenomenon, we postulate that asymptomatic mongrels infected with a wildtype strain of CDV might be disseminating the disease within urban canine populations of Brazil. Dogs without the typical clinical manifestations of distemper have been diagnosed with CDV by RT-PCR in Londrina/PR (AMUDE; ALFIERI; ALFIERI, 2006; 2007a) and Belo Horizonte/MG (DEL PUERTO et al., 2010). Restriction fragment length polymorphism analyses of vaccine and wild-type strains of the $\mathrm{H}$ gene of $\mathrm{CDV}$ used in Brazil have suggested that there are molecular differences existing between the vaccine strains of CDV circulating in northern Paraná and those strains attributed to clinical disease in susceptible dogs (NEGRÃO et al., 2006). Moreover, 22\% of all dogs vaccinated in Belo Horizonte/MG were infected by CDV (GOUVEIA; MAGALHÃES; RIBEIRO, 1987). Additionally, infected dogs that have been recently protected by attenuated CDV vaccines are thought to have been contaminated due to exposure of wild-type CDV (KAPIL et al. 2008). This hypothesis can be easily investigated by the utilization of a highly sensitive multiplex nested RT-PCR protocol (SI et al., 2010) and/or by a qualitative ELISA and neutralization assays of the T-cell response (PERRONE; BENDER; NIEWIESK, 2010); both methods have been successfully designed and tested to differentiate between wild-type and vaccine strains of CDV. Alternatively, it was suggested that the large amount of distemper in adult dogs might be related to inadequate vaccination (SILVA et al., 2009); nevertheless, these animals would theoretically have some form of protection and would have to become in contact with an infected animal to develop the disease. These arguments further stressed the urgent 
need for molecular epidemiological and genetic studies be designed in Brazil to further identify and discriminate the strains of CDV that are circulating in urban canine populations relative to those used in commercial vaccine production, in an attempt to elucidate the cause of the elevated mortality in dogs protected with attenuated vaccination protocols. Additionally, the possibility of manufacturing new vaccines must also be considered as novel strains of CDV are being discovered (WOMA et al., 2010).

\section{Economic impacts of canine distemper virus- induced manifestations}

Estimating the economic impacts due to routine therapy and veterinary consultation fees associated with CDV-induced clinical manifestations of dogs has never been attempted in Brazil. Therefore, the associated costs were estimated based on available scientific data. Studies realized in Brazil have estimated that the human: dog ration varies between 3.6-9.14 (SERAFIN et al., 2011), which reflects the variation in urban population density from the states of São Paulo, Paraná, and Pernambuco. However, if we were to use the study done in São Paulo as an average for Brazil urban populations, where the estimated human: dog ration is 5.14 (DIAS et al., 2004), there will be approximately $36,130,878$ dogs circulating in Brazilian cities, considering data released from the recent population census (IBGE, 2011). Epidemiological data obtained from the city of Santa Maria/RS, by three independent studies (HEADLEY; GRAÇA, 2000; SILVA et al., 2007; FIGHERA et al., 2008), has estimated that CDV is responsible for the death of approximately $12 \%$ of all dogs submitted for routine necropsy at The Veterinary Teaching Hospital (VTH)/Universidade
Federal de Santa Maria/RS. The estimated cost of treating (during normal commercial working hours) the basic clinical manifestations of systemic CDV infection (i.e., purulent bronchopneumonia, oculonasal purulent discharge, with myoclonus), in dogs that are either 10 or $25 \mathrm{~kg}$ of body weight (BW), without hospitalization but including veterinary consultation fees and a basic hematological analysis, at the VTH/Universidade Estadual de Londrina/PR (VTH-UEL), is approximately $\mathrm{R} \$ 58.00$ or $\mathrm{R} \$ 63.00$, respectively. Further, if we were to assume that all dogs $(12 \%)$ necropsied at VTHs were treated at least once, before euthanasia or spontaneous death, for the clinical manifestations of $\mathrm{CD}$, we can have an idea of the annual national cost to curb the clinical manifestations associated with CDV. These values are presented in Table 2, and suggest that therapy associated with the clinical manifestations of CDV in Brazil, without hospitalization (since dogs with clinical manifestations of CDV at the VTH-UEL are treated as out-patients), is estimated at $\mathrm{R} \$ 258.3$ million/annum (USD 147.6 million/annum) if all dogs died had $10 \mathrm{~kg} \mathrm{BW}$. If we consider, the BW for all dogs at $25 \mathrm{~kg}$, this figure increases to $\mathrm{R} \$ 280.5$ million/annum (USD 160.3 million/annum).

Although these figures are based purely on estimates, fixed numbers and values, and considered the worst case scenarios, the national annual economic impact associated with treating CDVinduced clinical manifestations is unbelievably astronomical, even if the actual values were 25 or $50 \%$ of these estimated annual costs. Nevertheless, this cost corresponds to $0.01-0.007 \%$ of the estimated nominal Growth Domestic Product (GDP) of Brazil for 2009/2010 for a $10 \mathrm{~kg} \mathrm{dog}$, and varies between $0.01-0.008 \%$ of the GDP for 2009/2010 for a $25 \mathrm{~kg}$ dog infected with CDV (Table 2). 
Table 2. Estimated national economic impact associated with the clinical manifestations of canine distemper virus.

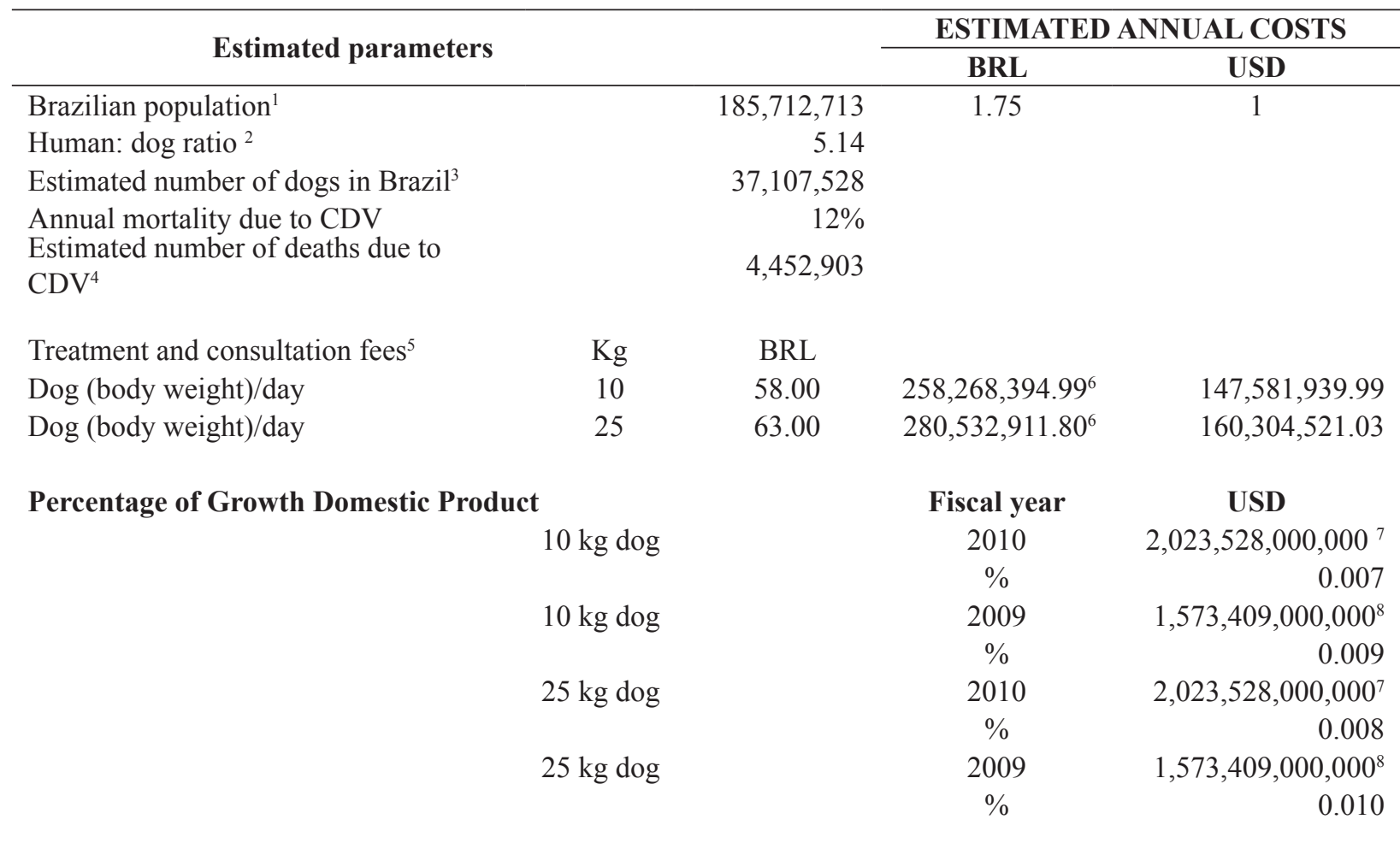

${ }^{1}$ IBGE, 2011; ${ }^{2}$ Dias et al., 2004; ${ }^{3}$ Headley; Graça 2000; Fighera et al., 2008; ${ }^{4}$ Considering that each animal would have been treated at least once at a Veterinary Hospital. ${ }^{5}$ Based on estimates obtained from the Veterinary Teaching Hospital, Universidade Estadual de Londrina; ${ }^{6} 1 \mathrm{USD}=1.661 \mathrm{BRL} ;{ }^{7}$ Wikipedia, 2011 (International Monetary Fund data); ${ }^{8}$ Wikipedia, 2011(World Bank data).

Sexual preference and age-related distribution patterns

Sexual predominance seems not to have any effect on infections by $\mathrm{CDV}$ in canids and wildlife species. Epidemiological and/or prevalence studies realized in Brazil have demonstrated no difference relative to the possibility of infection occurring between male and female dogs (HEADLEY; GRAÇA 2000; BORBA et al., 2002; DEZENGRINI; WEIBLEN; FLORES, 2007; HASS et al., 2008; GUEDES et al., 2010). However, in some studies, proportionally more males relative to females were infected by CDV. This was observed in Porto Alegre/RS, where male dogs contributed to $59 \%$ of the total number of dogs affected (SONNE et al., 2009), and with similar results being described in Madras city, India (ALEX; DHANAPALAN, 1994).
Neonates, recently weaned pups, and young dogs seem to be more frequently infected by CDV relative to older animals, confirming the agerelated susceptibility of infection (KRAKOWKA; KOESTNER, 1976), which is dependent on the viral strain (SUMMERS; GREISEN; APPEL, 1984) circulating within a specific geographical location. Under normal conditions, pups between 3-6 months of age are more susceptible than older animals (KRAKOWKA; KOESTNER, 1976) due to the decline in maternal antibody; young animals are normally protected by passive immunity, while older dogs should be protected by active vaccination (MARTELLA; ELIA; BUONAVOGLIA, 2008).

Tabulated data, based on seroprevalence or retrospective analysis, evaluating the age-related patterns of dogs infected by CDV in Brazil is controversial, since different age-related distribution 
patterns were used by each investigator. This makes the understanding and interpretation of the assembled data confused, and even misleading. A summary of the different age-range distributions is given in Table 3. We proposed that new epidemiological studies should adopt one of the several age-related distribution patterns already existing, so that the new data can be easily compared. Nevertheless, most studies that have used several age-related groups (HEADLEY; GRAÇA, 2000; BORBA et al., 2002; DEZENGRINI; WEIBLEN; FLORES, 2007; SILVA et al., 2009; SONNE et al., 2009; GUEDES et al., 2010) provide a better evaluation of disease progression as age increases; while a few used only three groups (GOUVEIA; MAGALHÃES; RIBEIRO, 1987; SILVA et al., 2007). In those studies with several age-related groups, pups and young dogs were comparatively more frequently infected by CDV relative to older animals; this is in agreement with the fact that young pups are not fully protected by passive immunization, whereas young dogs might not have been fully vaccinated and hence apt to be infected by CDV (GREENE; APPEL, 2006), on being exposed to a clinically or subclinically infected dog. However, the studies that used only three age related groups revealed that pups contributed to $45.9 \%$, adults $51.4 \%$, and aged animals represented $2.7 \%$ of all dogs with distemper encephalitis in Santa Maria/RS (SILVA et al., 2007), while in Belo Horizonte/MG it was shown that mature and older dogs contributed to $92.7 \%$ of dogs with clinical manifestations of distemper (GOUVEIA; MAGALHÃES; RIBEIRO, 1987). Nevertheless, these studies have all demonstrated that in Brazil distemper occurs in dogs of all ages, and the prevalence of infection might be elevated even in adult dogs. 


\section{Seasonal occurrence}

Studies realized in the southern Brazil have suggested that the highest prevalence of dogs diagnosed with CDV occurred during the winterspring period, with comparatively reduced prevalence during summer-autumn (HEADLEY; GRAÇA, 2000; BORBA et al., 2002); demonstrating a seasonal prevalence that corresponded to the coldest part of the year (Fig. 3). Epidemiological data obtained from Northern Brazil demonstrated that CD was more prevalent during the cold, humid, rainy season (GUEDES et al., 2010). Seasonal variations with elevated indices during the colder months have been described in CD (GORHAM, 1966; APPEL, 1987a; MARTELLA; ELIA; BUONAVOGLIA, 2008). Although the exact influence of seasonal variations on the occurrence of distemper is obscure, the colder weather facilities the maintenance (APPEL, 1987a; HEADLEY; GRAÇA, 2000) and increases the survival time of CDV (GREENE; APPEL, 2006), and might result in stress-induced immunosuppression in neonates and recently weaned dogs (HEADLEY; GRAÇA, 2000), facilitating infection in naïve animals. In CDV infection, immunosuppression probably occurs due to the lymphotrophism achieved by the binding of the $\mathrm{H}$ viral protein to cells that express the human equivalent to $\mathrm{CD}$ 150, signalling lymphocytic activation molecule; SLAM (BEINEKE et al., 2009; MACLACHLAN; DUBOVI, 2011). Although SLAM is expressed in healthy dogs, it is up-regulated in the lymphoid cells of dogs infected with CDV (BEINEKE et al., 2009), and expressed by thymocytes, activated macrophages, and dendritic cells (MACLACHLAN; DUBOVI, 2011). Therefore, destruction of cells that express SLAM might be the mechanism associated with immunosuppression in CD. Dogs that are immunocompromised due to CDV infections are apt to develop secondary bacterial (FAWI; TAG EL DIN; EL-SANOUSI, 1971; HEADLEY et al., 1999; MORETTI et al., 2006) or protozoan infections (MORETTI et al., 2002; 2006).

Figure 3. The effects of temperature (Temp) and relative humidity (RH) on the seasonal occurrence of 250 cases of canine distemper virus-induced infections during 1985 to $1997 .{ }^{1}$

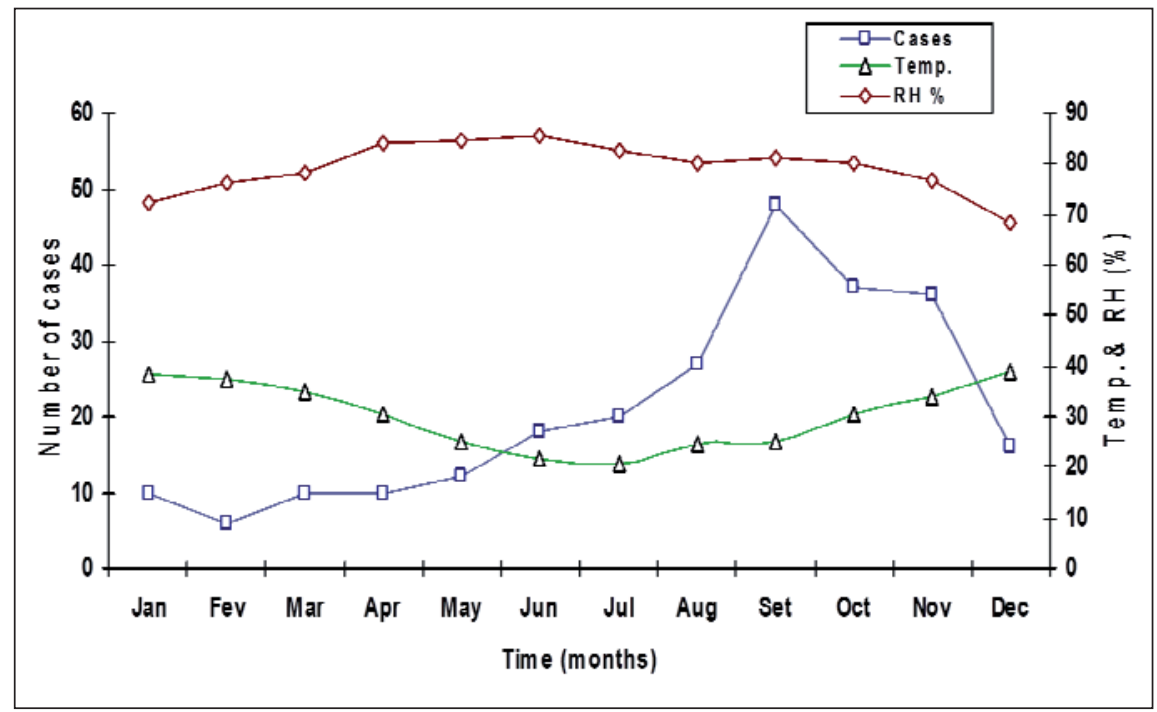

${ }^{1}$ Reproduced with the kind permission of the Brazilian Journal of Veterinary Research and Animal Science: HEADLEY, S. A.; GRAÇA, D. L. Canine distemper: epidemiological findings of 250 cases. Braz. J. Vet. Res. Anim. Sc., v. 37, p. 136-140, 2000. 
CDV has been reported as surviving near freezing temperatures between $0-4{ }^{\circ} \mathrm{C}$ for several weeks (GREENE; APPEL, 2006) and environmental stress has been associated with infection (MACLACHLAN; DUBOVI, 2011), which might favour elevated infectious rates during the colder climate. Alternatively, seasonal predominance of distemper in racoons has been attributed to the mating season (ROSCOE, 1993). Nevertheless, these results suggest that more epidemiological studies must be done in an attempt to verify the possible seasonal influence on the occurrence of distemper in susceptible animal populations.

\section{Neuropathological manifestations of canine distemper virus}

Clinico-neurological features of distemper
encephalitis

The clinic-neurological manifestations associated with CDV-induced lesions are diverse, and represent the neuroanatomical location affected. Although there is no definite correlation between clinical manifestations of neurological disease and the regions of the nervous system affected (SUMMERS; GREISEN; APPEL, 1984; TIPOLD; VANDEVELDE; JAGGY, 1992), myoclonus is considered characteristic (SUMMERS; CUMMINGS; DE LAHUNTA, 1994), or almost pathognomonic for CDE (TIPOLD; VANDEVELDE; JAGGY, 1992). Retrospective studies realized in Brazil have suggested that myoclonus is the most frequently observed neurological manifestation of distemper encephalitis in dogs (HEADLEY, 1999; SILVA et al., 2007), and with significant statistical variation in the age of affected animals (HEADLEY, 1999). In a study of 20 dogs from which eight were diagnosed with distemper encephalitis by histopathology and RT-PCR, tetraparesis/tetraplegia was the most frequent clinical manifestation and occurred in 87\% (7/8) of dogs diagnosed with CDE (AMUDE; ALFIERI; ALFIERI, 2007a). Some of the most commonly diagnosed neurological manifestations associated with distemper encephalitis are presented in Table 4. Other frequently observed clinical manifestations of neurological disease included: convulsions, opisthotonos, excessive salivation, paralysis, and motor incoordination (JONES; HUNT; KING, 1997; HEADLEY, 1999; SILVA et al., 2007). Additionally, cerebellar and vestibular neurological manifestations of CDV have been related to CDE (AMUDE; ALFIERI; ALFIERI et al., 2007a). The results of the clinical manifestation described in dogs with CDE in Brazil are similar to other studies (TIPOLD; VANDEVELDE; JAGGY, 1992; KOUTINAS et al., 2002). Nevertheless, it must be stressed that dogs are frequently diagnosed with neurological distemper without demonstrating clinico-neurological manifestation consistent with CDE (AMUDE; ALFIERI; ALFIERI, 2006; 2007a), suggesting that distemper encephalitis might be more frequent than is reported. 
Table 4. Principal neurological manifestations observed in 181 cases of canine distemper encephalitis ${ }^{1}$.

\begin{tabular}{|c|c|c|c|c|c|c|c|c|}
\hline \multirow{3}{*}{$\begin{array}{l}\text { Principal neurological } \\
\text { manifestations } \\
\text { (and frequency) }\end{array}$} & \multicolumn{8}{|c|}{ Age in years (and the number of dogs) } \\
\hline & \multicolumn{2}{|c|}{$\begin{array}{c}0-1.5 \\
(n=109)\end{array}$} & \multicolumn{2}{|c|}{$\begin{array}{c}1.6-3 \\
(n=32)\end{array}$} & \multicolumn{2}{|c|}{$\begin{array}{c}3.1-6 \\
(n=29)\end{array}$} & \multicolumn{2}{|c|}{$\begin{array}{l}6.1-12 \\
(n=11)\end{array}$} \\
\hline & $\%$ & $\mathrm{~N}^{\mathrm{o}}$ & $\%$ & $\mathrm{~N}^{\mathrm{o}}$ & $\%$ & $\mathrm{~N}^{\mathrm{o}}$ & $\%$ & $\mathrm{~N}^{\mathrm{o}}$ \\
\hline Myoclonus (72) & $39.45^{\mathrm{a}}$ & 43 & $50.00^{\mathrm{b}}$ & 16 & $31.03^{\mathrm{c}}$ & 9 & $36.36^{\mathrm{d}}$ & 4 \\
\hline Convulsions (26) & 16.51 & 18 & 12.50 & 4 & 6.90 & 2 & 18.18 & 2 \\
\hline Motor Incoordination (26) & 13.76 & 15 & 18.75 & 6 & 13.79 & 4 & 9.09 & 1 \\
\hline Salivation (15) & 11.93 & 13 & 3.13 & 1 & 3.45 & 1 & 0.00 & 0 \\
\hline Locomotion difficulties (13) & $6.42^{\mathrm{f}}$ & 7 & $12.50^{\mathrm{e}}$ & 4 & $3.45^{\mathrm{g}}$ & 1 & $9.09^{\mathrm{g}}$ & 1 \\
\hline Blindness (3) & 0.00 & 0 & 3.13 & 1 & 6.90 & 2 & 0.00 & 0 \\
\hline Paralysis (14) & 7.34 & 8 & 9.38 & 3 & 3.45 & 1 & 18.18 & 2 \\
\hline Paresthesia (6) & 1.83 & 2 & 3.13 & 1 & 6.90 & 2 & 9.09 & 1 \\
\hline Behavioral changes (6) & 2.75 & 3 & 6.25 & 2 & 3.45 & 1 & 0.00 & 0 \\
\hline Staggering gait (9) & 4.59 & 5 & 9.38 & 3 & 3.45 & 1 & 0.00 & 0 \\
\hline Photophobia (2) & 1.83 & 2 & 0.00 & 0 & 0.00 & 0 & 0.00 & 0 \\
\hline Circulatory movements (3) & 0.92 & 1 & 3.13 & 1 & 3.45 & 1 & 0.00 & 0 \\
\hline Opisthotonos (6) & 3.67 & 4 & 0.00 & 0 & 6.90 & 2 & 0.00 & 0 \\
\hline Paraplegia (1) & 0.92 & 1 & 0.00 & 0 & 0.00 & 0 & 0.00 & 0 \\
\hline Nystagmus (3) & 0.92 & 1 & 0.00 & 0 & 3.45 & 1 & 9.09 & 1 \\
\hline Hyperesthesia (1) & 0.92 & 1 & 0.00 & 0 & 0.00 & 0 & 0.00 & 0 \\
\hline
\end{tabular}

${ }^{1}$ Data tabulated as part of Masters Science Dissertation. Headley, 1999.

\$Number of dogs expressed as a percentage of the total number of dogs with the stated type of CDE lesion for each age range. Subscript letters (a, b, c, d, and e): percentages followed by different numbers in each row are significantly different (Chi-square Test; $P<0.0005$ ) from each other.

Neuropathological syndromes of canine distemper virus

Most retrospective studies done in Brazil have been based only on the histological patterns of CDE (HEADLEY; GRAÇA, 2000; HEADLEY; SOARES; GRAÇA, 2001; SILVA et al., 2007; 2009) to characterize the disease; there is a recent description of the combined usage of histopathology and IHC to diagnose distemper (SONNE et al., 2009). Although the lesions associated with $\mathrm{CDE}$ are unique, a diagnosis of distemper encephalitis based exclusively on histological patterns must be made with the concomitant finding of characteristic intranuclear/intracytoplasmic inclusion bodies (CASWELL; WILLIAMS, 2007). In CDE, viral inclusion bodies are more frequently observed in acute relative to chronic manifestations of disease, particularly due to the extremely complex, and not fully elucidated, immunopathological reactions associated with chronic distemper encephalitis (VANDEVELDE; ZURBRIGGEN, 1995; 2005; BEINEKE et al., 2009); readers are encouraged to examine these manuscripts for in-depth reviews of CDV-induced pathogenesis and immunological reactions. In basic terms, the initial lesions of distemper encephalitis are considered to be viral mediated, while progression to sclerosing plaque-like alterations observed in chronic distemper encephalitis is purely governed by immunopathological reactions (BEINEKE et al., 2009). Inclusion bodies are numerous during 10-14 days post infection (PI), and the number of inclusions 
is rapidly reduced 4-5 weeks PI (CASEWELL; WILLIAMS, 2007), these periods correspond, respectively, to the histological manifestations of acute and chronic CDE. Although CDV inclusions bodies were described as readily observed in 70 cases of CDE (SILVA et al., 2009), the finding of inclusion bodies is an arduous, painstaking, and time-consuming task particularly in chronic CDE, and as such is highly susceptible to induce false negatives. Consequently, we proposed that future retrospective and/or prospective studies in Brazil should use a combination of histopathology and IHC, aided with molecular biology, and particularly statistical analyses, so that the CDV-induced lesions can be effectively characterized and interpreted.

The progression of $\mathrm{CDE}$ as characterized by histopathology should be based on the patterns previously described (VANDEVELDE; FANKHAUSER; KRISTENSEN, 1981). The system proposed offers a simple and efficient characterization of histopathological alterations that can be readily observed and realized, thereby ensuring repeatability of results. Briefly, it characterises $\mathrm{CDE}$ into three distinct step-wise progressive lesions: acute, subacute, and chronic. Acute $\mathrm{CDE}$ is characterized by demyelination with discrete to moderate astrogliosis but without perivascular cuffs or inflammatory cells (Fig. 4A). Subacute CDE contains moderate demyelination with an influx of inflammatory cells, perivascular cuffing (formed by two or three layers of mononuclear cells), moderate astrogliosis and astrocytosis with discrete accumulations of macrophages (Fig. 4B). Chronic CDE would then be formed by demyelination with extensive perivascular cuffings (four or more layers of mononuclear cells), moderate to severe astrocytosis and astrogliosis, marked influx of lymphoplasmacytic and histiocytic inflammatory cells with multinucleated astrocytes (Fig. 4C). However, all patterns must demonstrate characteristic eosinophilic inclusion bodies (Fig. 4D).

Figure 4. Principal histological patterns of canine distemper virus-induced encephalitis. Observe severe white matter demyelination without perivascular cuffing and influx of inflammatory cells in acute distemper encephalitis (A). There is perivascular cuffing formed by at least two layers of mononuclear cells in subacute distemper encephalitis with discrete inflammatory influx (B). Chronic distemper encephalitis is characterized by perivascular cuffs formed by more than four layers of mononuclear cells with severe influx of inflammatory cells (C). Observe characteristic eosinophilic intranuclear inclusion bodies (arrows) within astrocytes (D). Hematoxylin and Eosin stain; Bar: A and C, $100 \mu \mathrm{m} ; \mathrm{B}, 50 \mu \mathrm{m} ; \mathrm{D}, 20 \mu \mathrm{m}$.

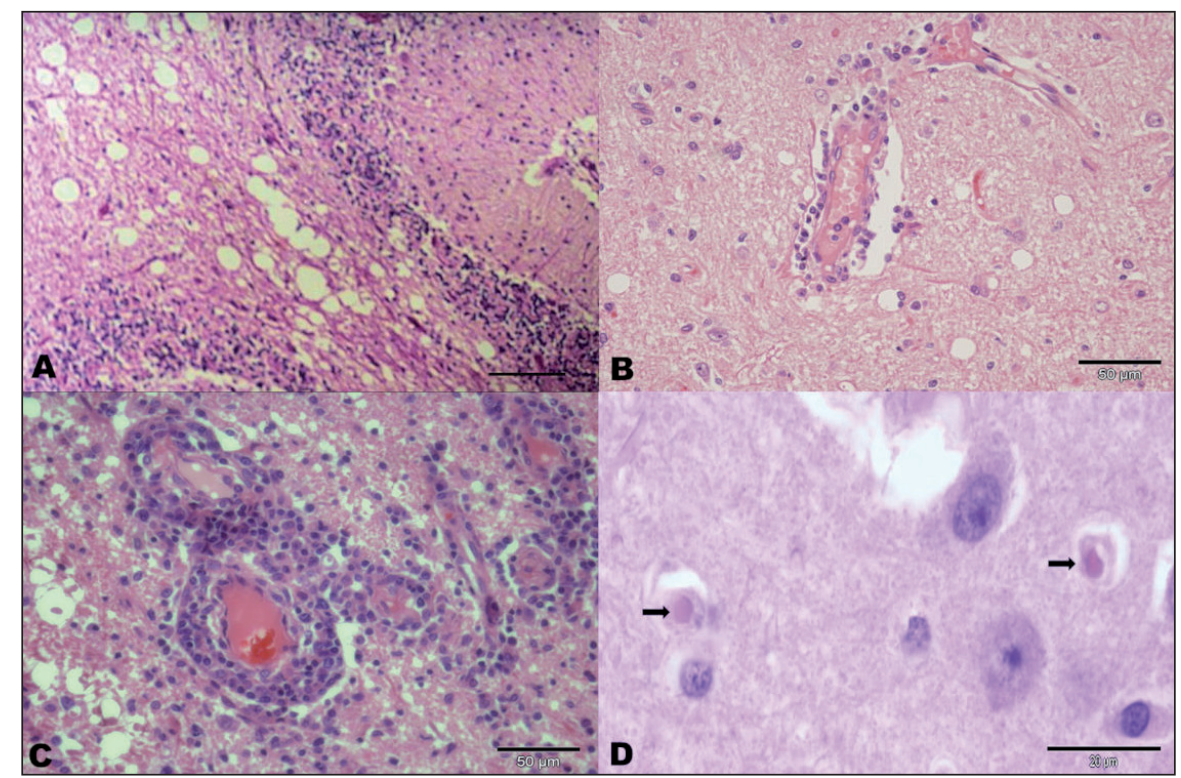

Source: Elaboration of the authors. 
It must be highlighted that this histological classification should be used only to evaluate the progression of $\mathrm{CDE}$, but is not synonymous for the clinical syndromes associated with CDV. Most syndromes associated with CDE are characterized principally by the neuroanatomical localization of the lesion, the histological features, the neurological manifestations, and to some extent, the age of the affected animal. Therefore, histological classification is fundamental to characterize CDV-related syndromes. However, data collected (between 1985-1997) has suggested that there is no significant statistical difference relative to the histological progression of CDE in dogs of different age-groups (Table 5), suggesting that the age of the dog might not have any influence on the manifestation of a particular histopathological manifestation of distemper encephalitis. Similar results were recently described (SILVA et al., 2009), and the authors have suggested that the utilization of age-related clinical syndromes of CDE might be an inappropriate form of classification. Therefore, more detailed epidemiological and statistically analysed data is needed before the exact relationship can be confirmed. Nevertheless, irrespective of the histological progression of disease, demyelination is probably the most frequently occurring manifestation of CDE (SILVA et al., 2009; SONNE et al., 2009), and histological manifestations of CDE are more frequently observed within the cerebellum (VANDEVELDE; FANKHAUSER; KRISTENSEN, 1981; JONES; HUNT; KING, 1997; SILVA et al., 2009), followed by the diencephalon, frontal lobe of the telencephalon, pons, and the mesencephalon (SILVA et al., 2009). Demyelination in CDE is considered more severe within the white matter of the cerebellum, rostral medullary velum, optic tracts, spinal cord, and around the fourth ventricle, and might be associated with viral dissemination via the cerebrospinal fluid (CASWELL; WILLIAMS, 2007).

Table 5. Age-related distribution in 181 cases of canine distemper encephalitis. ${ }^{1}$

\begin{tabular}{|c|c|c|c|c|c|c|c|c|}
\hline \multirow{3}{*}{$\begin{array}{c}\text { Histopathological } \\
\text { classification } \\
\text { (and number of cases) }\end{array}$} & \multicolumn{8}{|c|}{ Age range (in years) of dogs with the stated type of distemper encephalitis } \\
\hline & \multicolumn{2}{|c|}{$0-1.5$} & \multicolumn{2}{|c|}{$1.6-3$} & \multicolumn{2}{|c|}{$3.1-6$} & \multicolumn{2}{|c|}{$6.1-12$} \\
\hline & $\%^{\ddagger}$ & $\mathrm{N}^{\mathrm{o}}$ & $\%$ & $\mathrm{~N}^{\mathrm{o}}$ & $\%$ & $\overline{\mathrm{N}^{\circ}}$ & $\%$ & $\mathrm{~N}^{\mathrm{o}}$ \\
\hline Acute (74) & $45.0^{\mathrm{a}}$ & 49 & $34.4^{\mathrm{a}}$ & 11 & $31.0^{\mathrm{a}}$ & 9 & $45.4^{\mathrm{a}}$ & 5 \\
\hline Acute with necrosis (15) & $8.2^{\mathrm{c}}$ & 9 & $9.4^{\mathrm{c}}$ & 3 & $10.4^{\mathrm{c}}$ & 3 & $0^{\mathrm{e}}$ & 0 \\
\hline Subacute (78) & $40.4^{\mathrm{a}}$ & 44 & $46.8^{\mathrm{a}}$ & 15 & $51.7^{\mathrm{a}}$ & 15 & $36.4^{\mathrm{a}}$ & 4 \\
\hline Chronic (14) & $6.4^{\mathrm{d}}$ & 7 & $9.4^{\mathrm{c}}$ & 3 & $6.9^{\mathrm{d}}$ & 2 & $18.2^{\mathrm{b}}$ & 2 \\
\hline Total & 100 & 109 & 100 & 32 & 100 & 29 & 100 & 11 \\
\hline
\end{tabular}


Data relative to the predominant histological pattern of CDE in Brazil is controversial. Headley, Soares and Graça (2001) evaluating 43 cases of distemper encephalitis that were obtained from 250 dogs with manifestations of CDV infection (HEADLEY; GRAÇA 2000) suggested that subacute lesions $(51.2 \% ; 22 / 43)$ were more predominant relative to acute $(34.9 \% ; 15 / 43)$ and chronic $(13.9 \%$; 6/43) CDE. Amude, Alfieri and Alfieri (2007a) using eight cases of nonconventional distemper encephalitis that were obtained from 20 dogs with manifestations of neurological disease without typical CDV-induced clinic-neurological manifestations reported that chronic CDE was more predominant $(62.5 \% ; 5 / 8)$ relative to the acute manifestation of CDE. Silva et al. (2009) suggested that subacute (48.5\%) and chronic $(30.3 \%)$ manifestations were more prevalent than acute CDE (21.2\%) when a study of 70 cases of distemper encephalitis was analysed. Although these studies did not analyse the collected data statistically, it can be inferred that subacute distemper encephalitis might be the most frequently occurring manifestation of CDE in Brazil. This would then confirm the statistical tabulated data (Table 5) which suggested that early manifestations of distemper encephalitis are probably the most frequent in Brazil under natural conditions. Although the exact reason for these differences are unknown, biased data collection (AMUDE; ALFIERI; ALFIERI, 2007a) and differences in the strain of CDV (SILVA et al., 2009; SONNE et al., 2009) were suggested as possible explanations. The first is speculative and rather unlikely, since the data presented (HEADLEY; GRAÇA, 2000; HEADLEY; SOARES; GRAÇA, 2001; SILVA et al., 2009) were retrospectively collected from the same institution but in different time frames and represents the situation as presented at that particular moment. Although it is possible that antigenic variations could have resulted in the differences presented in these studies by separate investigators; this would have to be confirmed by phylogenetic evolutionary analyses of gene sequences from Rio Grande do Sul, but is not possible at the time of writing since no sequences from that geographical area have been identified in GenBank. This again highlights the importance of molecular epidemiological studies to investigate the complexities associated with CDV in Brazil. Nevertheless, current studies have suggested that there might be two strains of CDV circulating in Brazil (NEGRÃO et al., 2006; CASTILHO et al., 2007). Additionally, the series presented by Silva et al. (2009) related elevated indices (17\%) of laminar cortical necrosis particularly at the hippocampus, and it was suggested that this might be directly related to the infrequent observation of the hippocampus during routine histopathological evaluation of CDE, in addition to different strain of CDV.

Notwithstanding the above, there are several currently recognized neuropathological manifestations/syndromes of CDV-induced encephalitis. These vary with the neuroanatomical location of the lesion, the age and the immunological status of the affected animal, the histological pattern of disease, and viral strain (VANDEVELDE; FANKHAUSER; KRISTENSEN, 1981; SUMMERS; GREISEN; APPEL, 1984; BRAUND, 1994; SUMMERS; CUMMINGS; DE LAHUNTA, 1994). These neurological manifestations of CDV include: CDE in immature dogs, multifocal distemper encephalomyelitis in mature dogs, old dog encephalitis, post-vaccinal distemper encephalitis (BRAUND, 1994; SUMMERS; CUMMINGS; DE LAHUNTA, 1994; CASWELL; WILLIAMS, 2007; MAXIE; YOUSSEF, 2007), polioencephalomalacia (LISIAK; VANDEVELDE, 1979; FINNIE; HOOPER, 1984), and chronic relapsing encephalomyelitis (HIGGINS; CHILD; VANDEVELDE, 1989).

Neuropathological syndromes of CDE described in Brazil include: multifocal distemper encephalomyelitis in mature dogs (AMUDE et al., 2007b), old dog encephalitis (HEADLEY et al., 2009a), and more recently, what is being 
characterized as necrotizing CDV encephalitis in pups (AMUDE et al., 2011). A recent retrospective study characterized the neurological disease patterns of 70 cases as classical distemper encephalomyelitis irrespective of the age of the affected dogs (SILVA et al., 2009), and might have also occurred in the series presented by Headley, Soares and Graça (2001), since manifestations of specific neuropathological syndromes of CDE were not observed. However, these results could have been the negative effect of retrospective studies, where it would have been impossible to fully investigate a particular case that could have probably resulted in the description of a particular manifestation of CDE.

Distemper encephalitis in immature dogs: is considered the most commonly occurring manifestation of CDV (BRAUND, 1994), is widespread in Brazil and is frequently associated with systemic distemper in dogs with clinical manifestation and histological demonstrations of disease within, but not restricted to, the gastrointestinal, respiratory, urinary, and cutaneous systems. In some cases, enamel hypoplasia of developing teeth (HEADLEY; SAITO, 2003) due to the direct action of CDV on ameloblasts (DUBIELZIG, 1979), cutaneous abdominal pustules and myocardial necrosis (HEADLEY; SAITO, 2003) might be observed. Cutaneous pustules are manifestations of systemic CDV that has been complicated with staphylococcal and streptococcal infections (CASWELL; WILLIAMS, 2007). The neuropathological manifestations of disease are more frequently observed within the white matter of the cerebellar peduncles, the optic nerve, and the spinal cord (BRAUND, 1994; CASWELL; WILLIAMS, 2007). The histological lesions are characterized by varying degrees of demyelination, perivascular cuffings, degeneration of nerve fibres with the formation of spheroids, edema, neuronal necrosis (BRAUND, 1994; HEADLEY; SUKURA, 2009), neuroparenchymal necrosis and infiltration of macrophages in severe cases (BRAUND, 1994). In some cases there are severe accumulations of lymphoplasmacytic inflammatory cells within the choroid plexus (Fig. 5A) and the spinal cord (Fig. 5B). Intranuclear and/or intracytoplasmic eosinophilic inclusion bodies are readily observed within astrocytes, neurons, and within glial, ependymal and meningeal cells (HEADLEY; SUKURA, 2009), but are more frequently observed within astrocytes (APPEL 1987a; CASWELL; WILLIAMS, 2007). Positive immunoreactivity to CDV antigens are predominantly and easily observed by IHC within astrocytes of the cerebellar white matter (Fig. 5C), neurons of the spinal cord (Fig. 5D), and even in tissues where inclusion bodies are not easily identified by routine histology, such as in the choroid plexus (Fig. 5E) and the meninges (Fig. 5F). However, different from the cerebellum, positive immunoreactivity to CDV antigens within the cerebrum seems predominant within neurons relative to astrocytes (Fig. 5G-H). 
Figure 5. Distemper encephalitis in immature dogs. There is severe accumulation of lymphoplasmacytic infiltrate within the choroid plexus (A) and the spinal cord (B). Observe immunohistochemical demonstration of canine distemper virus antigens predominantly within astrocytes of the cerebellar white matter (C) and within neurons of the spinal cord (D). Positive immunoreactivity is also demonstrated within ependymal cells of the choroid plexus (E), and in meningeal and endothelial cells of the cerebellum (F). Observe positive immunoreactivity to antigens of canine distemper virus predominantly within neurons of the cerebrum ( $\mathrm{G}$ and $\mathrm{H})$. A-B, Hematoxylin and Eosin stain, Bar, 200 $\mu \mathrm{m}$; C-F, Immunoperoxidase, Bar C, E, F, and G, $200 \mu \mathrm{m}$; D and H, $20 \mu \mathrm{m}$.

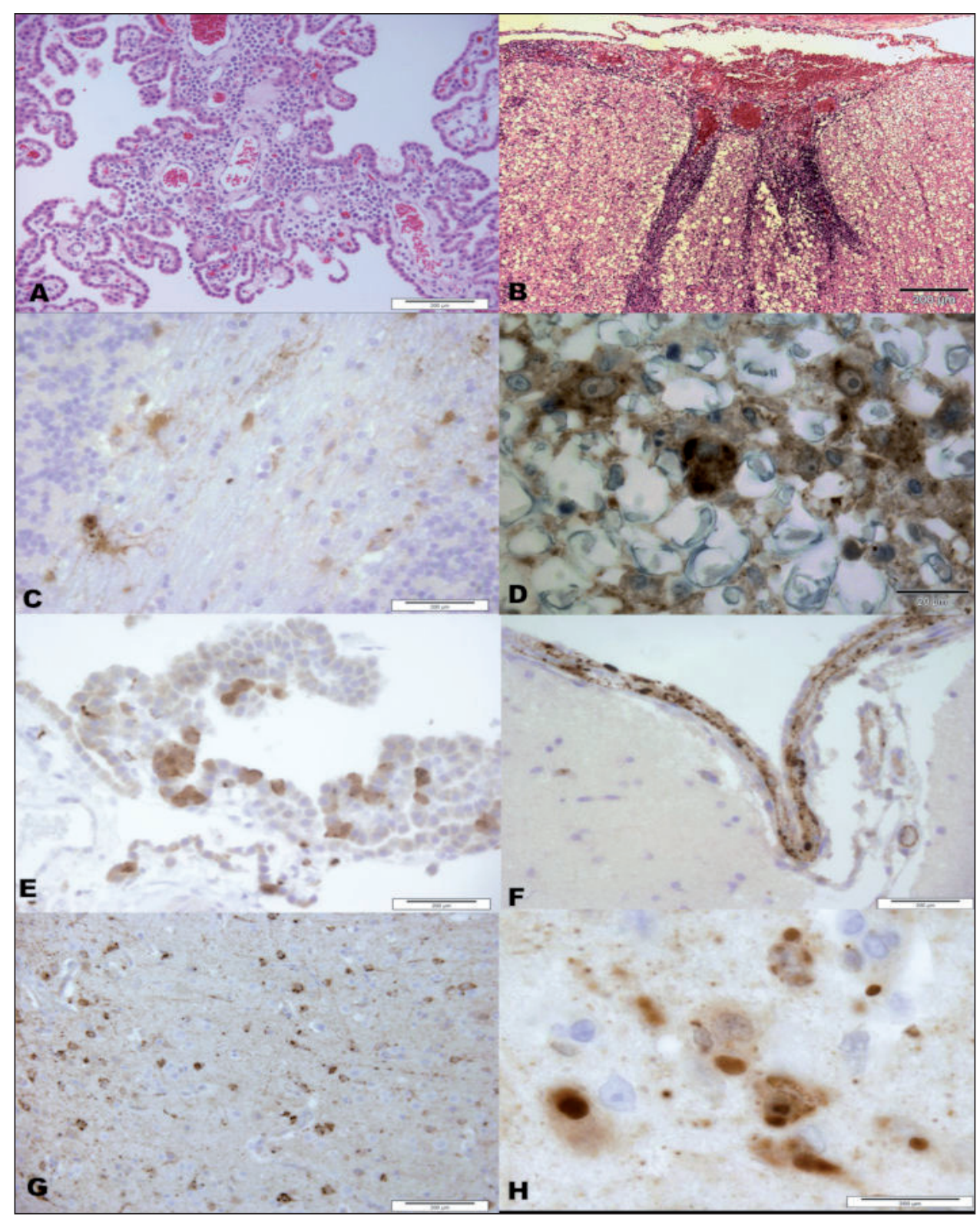

Source: Elaboration of the authors.

Multifocal distemper encephalomyelitis in that occurs in dogs that are between 4-8 years mature dogs: is an unusual syndrome of low incidence associated with CDV (BRAUND, of age (BRAUND, 1994; MAXIE; YOUSSEF, 1994; AMUDE; ALFIERI; ALFIERI, 2007b) and progressive (MAXIE; YOUSSEF, 2007), 
and includes nystagmus, positional ventrolateral strabismus, and spastic tetraparesis (AMUDE; ALFIERI; ALFIERI, 2007b), but without seizures and personality changes (MAXIE; YOUSSEF, 2007). The histological manifestations of disease are restricted to the CNS, being more prevalent within the cerebellum and spinal cord white matter, with sparing of the cerebral cortex (VANDEVELDE et al., 1980; MAXIE; YOUSSEF, 2007). This anatomic predominance of histological lesions for the cerebellum and spinal cord with the absence of cerebral involvement differentiates this syndrome from old dog encephalitis, in which the cerebrum is frequently affected (MAXIE; YOUSSEF, 2007; HEADLEY et al., 2009a). Histological alterations are characterized by multifocal necrotizing to demyelinating nonsuppurative encephalitis (AMUDE; ALFIERI; ALFIERI, 2007b; MAXIE; YOUSSEF, 2007), associated with rare inclusion bodies (BRAUND, 1994; MAXIE; YOUSSEF, 2007). In the only case described in Brazil, CDV was isolated from cell culture, RT-PCR amplified the $\mathrm{N}$ gene (formerly NP) of CDV, and the amplicons were sequenced confirming CDV participation (AMUDE; ALFIERI; ALFIERI, 2007b). In Brazil, this manifestation of CDE might be more prevalent than is described, and studies are being undertaken to characterize cases that might eventually be diagnosed as CDE in mature dogs

Old dog encephalitis (ODE): is a very rare and unusual manifestation of CDV-induced encephalitis that occurs in dogs that are more than six years of age (BRAUND, 1994; MAXIE; YOUSSEF, 2007; HEADLEY et al., 2009a), but animals as young as 1 year of age have been diagnosed with this disease (MAXIE; YOUSSEF, 2007). The absence of reported cases of ODE during decades after the initial descriptions of this disease (CORDY, 1942; ADAMS et al., 1975; LINCOLN et al., 1971; 1973; VANDEVELDE et al., 1980), had resulted in speculation as to the existence of this unique manifestation of CDV since spontaneous cases have not been observed in several institutions (BRAUND, 1994), and it was suggested that some of the previously reported cases of ODE might have been CDE in older dogs (SUMMERS; APPEL, 1994). This uncertainty was probably supported due to the difficulty and successive frustrated attempts to isolate and transmit the virus in vitro (CORDY, 1942; ADAMS et al., 1975; LINCOLN et al., 1971; 1973), probably because in ODE, CDV appears to persist in a replication-defective state (SUMMERS; APPEL, 1994; MAXIE; YOUSSEF, 2007). However, the disease was experimentally reproduced in a gnotobiotic dog (AXTHELM; KRAKOWKA, 1998), and more recently a spontaneous case was described in Londrina/PR (HEADLEY et al., 2009a). These recent descriptions confirm that this manifestation of CDE exists, but is indeed rarely diagnosed.

Clinically, ODE is characterized by progressive cortical and subcortical dysfunction with manifestations of mental depression, unresponsive behaviour, head pressing (BRAUND, 1994), circling, swaying, and weaving gait (MAXIE; YOUSSEF, 2007), motor incoordination, behavioural changes, and seizures (HEADLEY et al., 2009a). Systemic manifestations of CDV are absent in ODE (BRAUND, 1994; JONES; HUNT; KING, 1997), and visual impairment might be the initial manifestation of this syndrome (BRAUND, 1994). The neuropathological alterations are restricted to the forebrain with marked sparing of the hindbrain (cerebellum and brain stem) and occipital cortex (MAXIE; YOUSSEF, 2007; HEADLEY et al., 2009a). In the case described in Londrina/PR, gross manifestation of disease included loss of distinct demarcation between the white and grey matter, with an irregular surface and marked grey-brown discoloration to the affected tissue; these changes are more easily appreciated when the affected region is compared with the normal tissue (Fig. 6). 
Figure 6. Gross demonstration of forebrain lesion in old dog encephalitis; formalin-fixed sections. The normal brain is shown with the neuroanatomical locations $(1,2$, and 3$)$ where gross manifestations were predominant (A). The normal section (B) for comparison was taken at transverse location 3 and compared with the similar but affected region (C), and demonstrated the marked absence of differentiation between the white and grey matter due to inflammation and degeneration $(\mathrm{C})$.

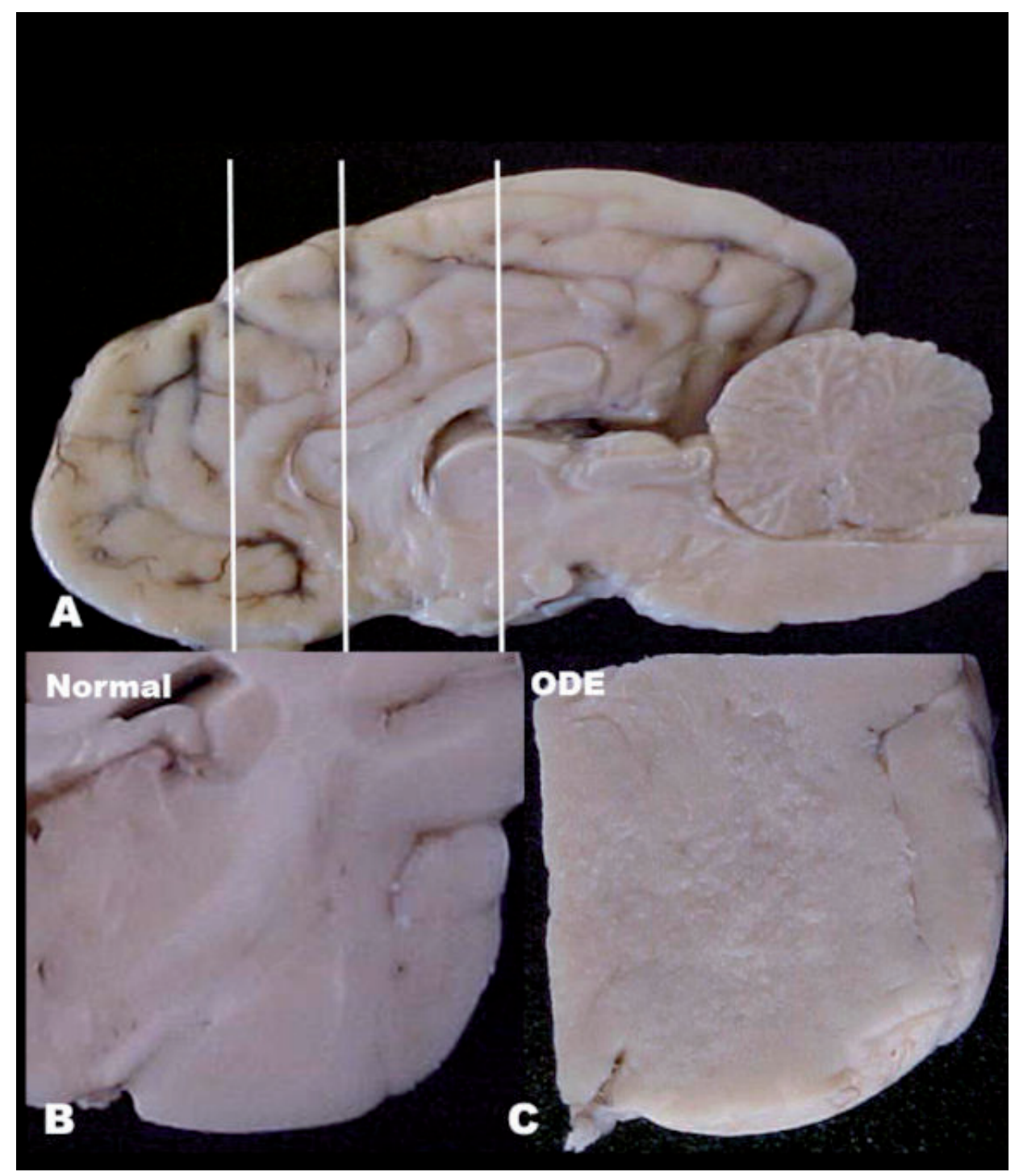

Source: Elaboration of the authors.

Histological alterations are restricted to VANDEVELDE et al., 1980; HEADLEY et al., the forebrain and consist predominantly of 2009a). Most perivascular cuffs contained more extensive perivascular cuffs, severe influx of than six layers of mononuclear cells (Fig. 7A) lymphoplasmacytic inflammatory cells, marked and multinucleated giant cells frequently contain glial proliferation, neuronal necrosis, rarefaction inclusion bodies (Fig. 7B-C). Inclusion bodies of neuroparenchymal, and accumulations of in ODE are considered either to be frequent multinucleated giant cells (CORDY, 1942; (LINCOLN et al., 1971; 1973; VANDEVELDE LINCOLN et al., 1971; ADAMS et al., 1975; et al., 1980; HEADLEY et al., 2009a), infrequent 
(CORDY, 1942), or absent (AXTHELM; KRAKOWKA, 1998). Immunohistochemical studies of the case described in Londrina/PR readily demonstrated $\mathrm{CDV}+$ antigens predominantly within neurons relative to astrocytes (Fig. 7D), but with weak immunoreactivity within syncytial cells. Additionally, the multinucleated giant cells previously described in other cases of ODE (LINCOLNetal., 1971;AXTHELM;KRAKOWKA, 1998), were strongly immunoreactive to vimentin and macrophage antigen, but were negatively labelled with glial fibrillary acidic protein, CD3, and CD79a, suggesting that these cells are more likely of a monocytic origin (HEADLEY et al., 2009a). Additionally, the N gene (formerly NP) of CDV was successfully extracted from formalinfixed paraffin-embedded tissues, amplified by RTPCR, the amplicons sequenced, and the obtained nucleotide sequences have been deposited in GenBank (HEADLEY et al., 2009a), representing the first characterization of this gene in ODE. The viral strain (Accession number EF197736) identified in this dog is antigenically similar to other strains of CDV circulating in Brazil, USA, and Europe (Fig. 2A-B). It must be stressed, that this method of RNA extraction is of outmost importance for diagnostic pathology, since it can be readily utilized for retrospective studies by using paraffinembedded blocks.

Atypical necrotizing encephalitis of young pups: is a recently diagnosed, not previously described atypical manifestation of systemic CDE (AMUDE et al., 2011). The disease occurred in a litter of pups that were less than one month of age, being characterized by clinical manifestations of bilateral forebrain dysfunction (decreased to absent postural reactions, normal spinal reflex, seizures, and decreased level of consciousness without cranial nerves deficits). Neuropathological manifestations of disease were restricted to the gray and white matters of the forebrain (telencephalon and diencephalon) with sparing of the hindbrain (cerebellum, cerebellar peduncles, pons, and medulla oblongata). Histopathological alterations were restricted to the forebrain, and were characterized by asymmetrical necrosis with severe influx of monocytic and histiocytic inflammatory cells, syncytial formation, severe astrocytic response associated with intranuclear and intracytoplasmic eosinophilic inclusion bodies within glial cells. Further, intralesional antigens of CDV were demonstrated by $\mathrm{IHC}$, and the $\mathrm{N}$ gene of $\mathrm{CDV}$ was amplified by RT-PCR from fresh tissue fragments from the brain and visceral organs. Atypical necrotizing encephalitis of young pups is unique in that it affects only the forebrain of dogs with systemic $\mathrm{CD}$; hence the neuroanatomical localization of this disease differentiates this syndrome from other known manifestations of CDE. However, the pathological manifestations of this syndrome must be differentiated primarily from those associated with canine herpes virus 1 (CaHV-1) in neonates. CaHV1 produces multifocal necrosis that is frequently observed within several parenchymal organs (liver, kidney, lungs, thymus, and spleen) as well as the intestines and brain (APPEL, 1987b; MAXIE; YOUSSEF, 2007), with discrete manifestations of disease affecting the stomach, pancreas, omentum, retina, and myocardium (APPEL, 1987b). The neuropathological manifestations of CaHV-1 encephalitis are characterized by severe nonsuppurative meningoencephalitis primarily affecting the cerebellum and brain stem (MAXIE; YOUSSEF, 2007), with cerebral cortical necrosis and necrosis of the thalamus, and hemorrhage, lymphoplasmacytic inflammatory infiltrate and perivascular cuffing within the cerebrum, cerebellum, thalamus, pons and medulla (APPEL, 1987b). 
Figure 7. Histological and immunohistochemical findings in old dog encephalitis. There is severe destruction of brain tissue due to extensive perivascular cuffs and severe influx of inflammatory cells (A). Several multinucleated giant cells were observed admixed within the inflammatory infiltrate (B) and some of these (arrow) contained viral inclusion bodies (C). Observe positive immunoreactivity to antigens of canine distemper virus within neurons and astrocyte (D). Multinucleated giant cells demonstrated positive immunoreactivity to vimentin (E) and macrophage antigen (F).

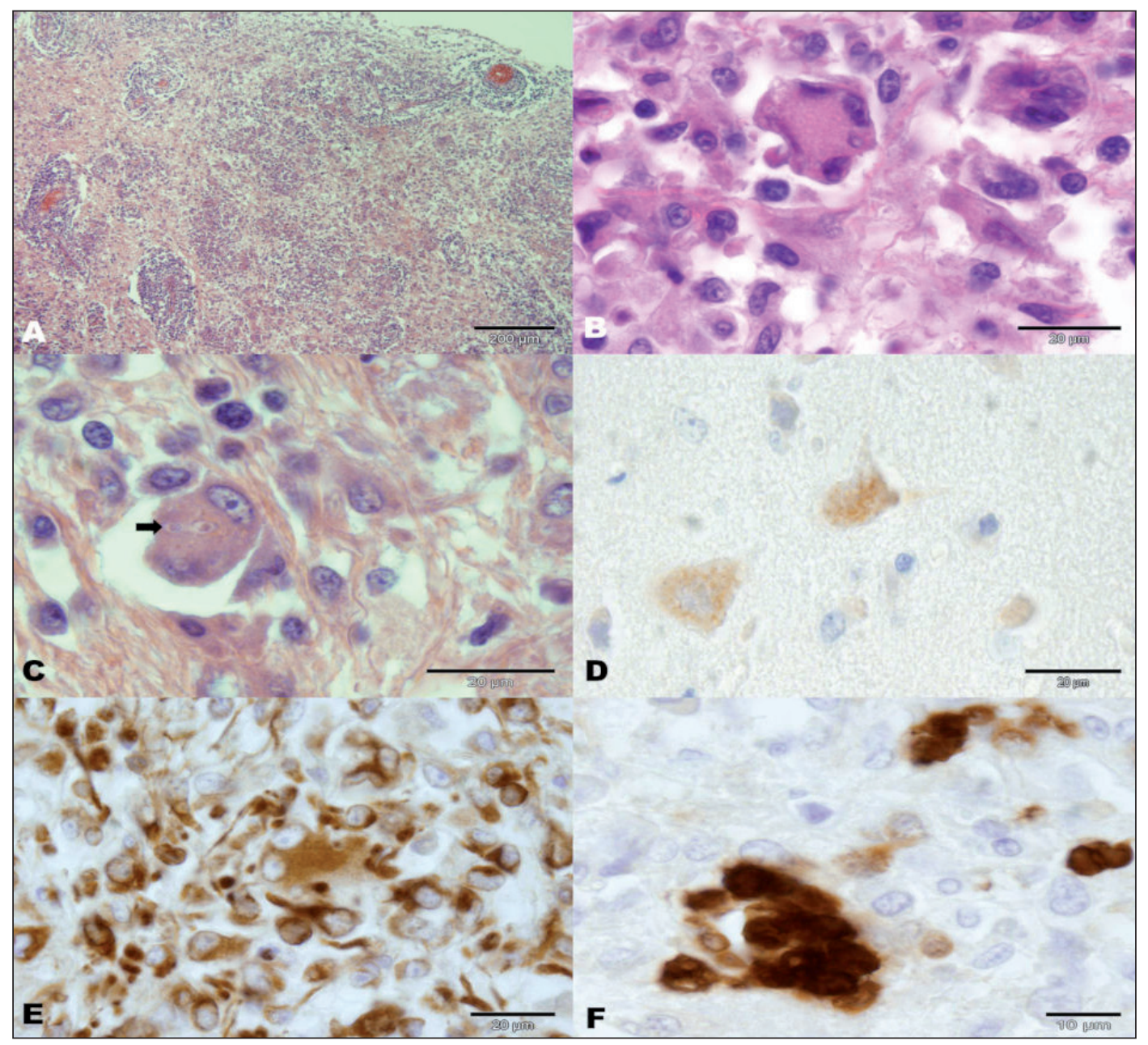

Source: Elaboration of the authors.

\section{Public health concerns}

CDV has been incriminated as the possible etiologic agent of two well-known human diseases: multiple sclerosis (MS) and Paget's disease of bone (PDB). These are highly controversial and furiously debated issues within the scientific community; this review would have been incomplete if the association or not of CDV was not discussed, and the authors would have failed in their responsibility as veterinarians concerned with public health.
MS is a chronic progressive inflammatory disease of the brain that is characterized by demyelination, severe accumulation of inflammatory cells, gliosis, and axonal degeneration, which begin in early adulthood (KAKALACHEVA; MÜNZ; LÜNEMANN, 2011). Similarhistological alterations are observed in some forms of chronic distemper encephalitis which resulted in CDE being proposed as a model to study MS and subacute sclerosing panencephalitis (KOESTNER, 1975). Due to the abrupt increasing incidence of MS during the two 
decades immediately after the Second World War in the Faroe Islands which coincided with an outbreak of $\mathrm{CD}$ and the arrival of British troops during the war, CDV or a closely related virus was proposed as the etiologic agent of MS (COOK DOWLING; RUSSEL, 1978). A similar concomitant increase in cases of MS in humans coincided with outbreaks of CD in Iceland (COOK; DOWLING; RUSSEL, 1979) and later in Key West, Florida/USA (COOK et al., 1987). This CDV related MS theory gained support from several epidemiological questionerbased surveys which tried to establish an association of MS with household dogs and also with dogs having neurological disease (COOK; DOWLING, 1977; JOTKOWITZ, 1977), and from serological observations that detected antibodies of the $\mathrm{H}$ protein gene of CDV in humans with MS (ROHOWSKYKOCHAN; DOWLING; COOK, 1995). However, other epidemiological surveys (READ et al., 1982; ANDERSON et al., 1984) and serological studies (KRAKOWKA; KOESTNER, 1978; GORHAM; HABICHT; LACHMANN, 1980; APPEL et al., 1981) have not confirmed the likelihood of CDV being associated with MS. Further, an extensive epidemiologic study done throughout the USA by the National Cancer Institute in association with the national database of Veterinary School in the USA and Canada did not find any correlation between CDV and MS (KURTZKE; PRIESTER, 1979).

Recent studies have suggested that viralinduced trigger mechanisms coupled with genetic predisposition and environmental influences might be the key factors to explain the pathogenesis associated with MS (LINCOLN; HANKIEWICZ; COOK, 2008; KAKALACHEVA; MÜNZ; LÜNEMANN, 2011). Viral agents with elevated possibility of inducing these mechanisms include: Epstein-Bar virus, the causative agent of asymptomatic infection in childhood or adult life (LINCOLN; HANKIEWICZ; COOK, 2008; KAKALACHEVA; MÜNZ; LÜNEMANN, 2011); varicella-zoster virus, the etiologic agent of chickenpox; human herpesvirus-6, which causes lymphoproliferative disease; and human endogenous retroviruses, that has been isolated from the body fluids and cerebrospinal fluid of MS patients (KAKALACHEVA; MÜNZ; LÜNEMANN, 2011). While there is reduced possibility of CDV being associated with the etiopathogenesis of MS (LINCOLN; HANKIEWICZ; COOK, 2008). Although Brazil and other South Americana countries are considered as a low risk geographical locations for MS (KAKALACHEVA; MÜNZ; LÜNEMANN, 2011), there have been increasing epidemiological studies investigating MS in Brazil (ARRUDA et al., 2001; CARDOSO et al., 2006; FRAGOSO; PERES, 2007; FINKELSZTEJN et al., 2009), and also in Argentina (MELCON et al., 2008). The studies conducted in Brazil occurred in the cities of Curitiba/PR (ARRUDA et al., 2001), Salvador/BA (CARDOSO et al., 2006); Santos/SP (FRAGOSO; PERES, 2007), and Porto Alegre/RS (FINKELSZTEJN et al., 2009); a list of epidemiological studies of MS in Brazil is presented by Finkelsztejn et al. (2009). The prevalence of MS in north-eastern regions of Brazil is estimated at $5 \%$, and $15 \%$ to $18 \%$ within the south-south eastern regions (CARDOSO et al., 2006). Most studies have demonstrated that females are more predisposed to MS than males, with predominance of cases in patients of Caucasian relative to African descent (ARRUDA et al., 2001; CARDOSO et al., 2006; FRAGOSO; PERES, 2007; FINKELSZTEJN et al., 2009). Although, it has been established that immigrants from areas of elevated risk for MS who have migrated, before 16 years-of-age, to a low-risk geographical location are likely to maintain their risk-factor (DEAN et al., 1976), this phenomenon was not investigated in the epidemiological studies analysed considering the impact of European immigration on the development of Brazil. Further, epidemiological surveys to exclude the possibility of CDV having any effect on MS in Brazil were not localized.

PDB is a chronic bone disorder that is characterized by increased ostoeclastic and 
osteoblastic activity in several locations of the skeleton (RALSTON et al., 1991). PDB was first described by Sir James Paget in 1877, and considered as prevalent in elderly populations of Europe, USA, and Australia (MEE; SHARPE, 1993). In Brazil, the occurrence of PDB seems to be restricted to Recife/ PE, with predominance in patients of European descent (GRIZ et al., 2006); since cases have not been described in other geographical regions. The true etiology of PDB is currently unknown, but studies have implicated paramyxoviruses, including $\mathrm{CDV}$, measles virus (MV), respiratory syncytial virus, parainfluenza virus-3, and simian virus (MEE; SHARPE, 1993) as possible etiologic agents. However, the controversy seems to be with CDV and between the results of investigators from distinct British laboratories.

The controversy relative to the possibility of a virus associated etiology of PDB began after viral nuclear inclusion bodies, identified by electron microscopy, were described within osteoclasts of patients with this bone disorder (MILLS; SINGER, 1976). Thereafter, and similar to the MS controversy, an association between household pets and PDB was made by epidemiological studies (O'DRISCOLL; ANDERSON, 1985; O'DRISCOLL et al., 1990), and this likelihood was increased when mongrels or unvaccinated dogs were evaluated (KHAN et al., 1996). Studies using in situ hybridisation have observed that only CDV-N antisense probes hybridized with CDV RNA within osteoclasts, osteoblasts, and osteocytes of patients with PDB (GORDON; ANDERSON; SHARPE, 1991; GORDON et al., 1993); similar results were also observed with in situ-reverse RT-PCR (MEE et al., 1998). Further, CDV N gene was identified by in situ hybridisation and RT-PCR from bone cells of dogs diagnosed with metaphyseal osteopathy (MEE et al., 1993), a canine bone disease of uncertain etiology but with some similar histological features of PDB (MEE; SHARPE, 1993; MEE et al., 1993). However, antagonistic results not in support of this theory were observed by PCR (RALSTON et al., 1991), while a comparative blinded study has suggested that cross-contamination due to the excessive usage of various diagnostic techniques, within the same laboratory, to evaluate the participation of CDV in PDB could have been responsible for the results described by MEE and collaborators (RALSTON et al., 2007).

Nevertheless, experimental studies have demonstrated CDV antigens within bone marrow cells, osteoblasts, osteoclasts, and osteocytes of young dogs; these lesions were associated with metaphyseal bone lesions, which were most prominent between PI 8 and PI 32, and were characterized by osteoclast necrosis and persistence of primary spongosa (BAUMGÄRTNER et al., 1995a). This study confirmed previous descriptions of the participation of CDV in natural and experimentally-induced bone lesions of young dongs (BAUMGÄRTNER et al., 1995b), but it is unknown if this represents a separate CDV-induced bone disease or a manifestation of systemic CDV (BAUMGÄRTNER et al., 1995a). The marked difference between the studies of experimental and natural CDV-induced infections of dogs and those with PDB was that both sense and antisense probes were bound to bone cells when in situ hybridization was used (BAUMGÄRTNER et al., 1995a), whereas only CDV sense probes were bound to bone cells in human cases of PDB (GORDON; ANDERSON; SHARPE, 1991; GORDON et al., 1993).

\section{Conclusions}

Canine distemper virus is endemic throughout Brazil and is one of the principal causes of mortality in urban canine populations, even in dogs that have been vaccinated. Dogs from different age groups and of both sexes are highly susceptible to CDV infection. The direct relationship of seasonal predominance relative to infection is not well elucidated, but the colder season apparently favours infection. There are relatively few reports of CDV diagnosed in Brazilian wildlife relative to 
other countries, where $\mathrm{CD}$ is associated with the extinction of specific species of wildlife. This might suggest that the epidemiological situation in Brazil might be different from those countries where several species of non-domestic dogs are considered as alternative candidates to serve as reservoirs and hence disseminate distemper in susceptible canine and wildlife species. Prophylactic and control strategies aimed at mongrel dogs might be the key to reduce the elevated indices of distemper in urban canine populations in Brazil and to prevent the dissemination of distemper to susceptible wildlife, since this specific canine population might be the reservoir of $\mathrm{CDV}$ in rural and semi-urban canine populations. The cost associated with treating the manifestations of distemper can be considerable reduced if adequate vaccination can be extended to roaming dogs. Molecular epidemiological studies are required so that epizootics associated with CDV can be fully understood, but initial studies suggest that two strains of CDV might be circulating in Brazil. Subacute CDE might be the most prevalent neuropathological manifestation of $\mathrm{CDV}$, and the usage only of age-related clinical syndromes of CDV might not be the adequate classificatory method for the manifestations of CDE in Brazil. Additional retrospective and prospective studies are needed in Brazil to fully understand the complexities associated with the evolutionary trends of CDV, and atypical manifestations of CDE are likely to occur as CDV adapts in susceptible hosts. The participation of CDV in MS and PDB is controversial and remains uncertain, and more studies are needed to elucidate the etiopathogenesis of these intriguing diseases. Nevertheless, since CDV has infected a wide-range of vertebrate host, it will not be surprising, if due to the close proximity of man and dog, which has become more so in the last few decades, that CDV is confirmed as the etiologic agent of a human disease. Finally, although CD has been known since 1746, aspects of the pathogenesis and evolution of CDV continue to elucidate and fascinate investigators worldwide.

\section{Acknowledgements}

Drs. S.A. Headley, A.F. Alfieri, A.P.F.R.L. Bracarense, and A.A. Alfieri are recipients of CNPq fellowships. The authors thank Dr. Ney Carlos Reichert Netto, the Administrator, Veterinary Teaching Hospital, Universidade Estadual de Londrina/PR, for the utilization of data in this article. Appreciation is also extended to Drs. Eduardo S. Sakaguti and Ricardo Pereira Ribeiro, Departamento de Zootecnia, Universidade Estadual de Maringá, for statistical analyses. Gratitude is expressed to Kati Holmsten, University of Helsinki, for some of the histological and immunohistochemical preparations used in this manuscript.

\section{References}

ADAMS, J. M.; BROWN, W. J.; SNOW, H. D.; LINCOLN, S. D.; SEARS JUNIOR, A. W.; BARENFUS, M. T.; HOLLIDAY, T. A.; CREMER, N. E.; LENNETTE, E. H. Old dog encephalitis and demyelinating diseases in man. Veterinary Pathology, Washington, v. 12, n. 3, p. 220-226, 1975.

ALEX, P. C.; DHANAPALAN, P. D. Distemper encephalitis in dogs: incidence, symptomatology, and electroencephalographic findings. Journal of Veterinary and Animal Sciences, v. 25, p. 127-131, 1994.

AMUDE, A. M.; ALFIERI, A. A.; ALFIERI, A. F. Antemortem diagnosis of CDV infection by RT-PCR in distemper dogs with neurological deficits without the typical clinical presentation. Veterinary Research Communication, Netherlands, v. 30, n. 6, p. 679-687, 2006.

distemper encephalomyelitis presented without characteristic signs of the disease. Research in Veterinary Science, London, v. 82, n. 3, p. 416-422, 2007a.

AMUDE, A. M.; CARVAlHO, G. A.; ALFIERI, A. A.; ALFIERI, A. F. Virus isolation and molecular characterization of canine distemper virus by RT-PCR from a mature dog with multifocal encephalomyelitis. Brazilian Journal of Microbiology, São Paulo, v. 38, p. 354-356, $2007 \mathrm{~b}$.

AMUDE, A. M.; HEADLEY, S. A.; ALFIERI, A. A.; BELONI, S. N. E.; ALFIERI, A. F. Atypical necrotizing encephalitis associated with systemic canine distemper 
virus infection in pups. Journal of Veterinary Science, Seoul, v. 12, n. 4, p. 409-411, 2011.

ANDERSON, L. J.; KIBLER, R. F.; KASLOW, R. A.; AUSTIN, J.; HOLMAN, R. C. Multiple sclerosis unrelated to dog exposure. Neurology, Minneapolis, v. 34, n. 9, p. 1149-1154, 1984.

APPEL, M. Canine distemper virus. In: APPEL, M. J. Virus infections of vertebrates. Amsterdam: Elsevier, v. 1, cap. 13, p. 133-159, 1987a.

Canine herpesvirus. In: APPEL, M. J. Virus infections of vertebrates. Amsterdam: Elsevier, v. 1, cap. 1, p. 5-15, $1987 \mathrm{~b}$.

APPEL, M. J.; GLICKMAN, L. T.; RAINE, C. S.; TOUTELlOTTE, W. W. Canine viruses and multiple sclerosis. Neurology, Minneapolis, v. 31, n. 8, p. 944949, 1981.

APPEL, M. J. G.; YATES, R. A.; FOLEY, G. L.; BERNSTEIN, J. J.; SANTINELLI, S.; SPELMAN, L. H.; MILLER, L. D.; ARP, L. H.; ANDERSON, M.; BARR, M.; PEARCE-KELLING, S.; SUMMERS, B. A. Canine distemper epizootic in lions, tigers, and leopards in North America. Journal of Veterinary Diagnostic Investigation, Columbia, v. 6, n. 3, p. 277-288, 1994.

ARRUDA, W. O.; SCOLA, R. H.; TEIVE, H. A. G.; WERNECK, L. C. Multiple sclerosis: report on 200 cases from Curitiba, Southern Brazil and comparison with other Brazilian series. Arquivos de Neuropsiquiatria, São Paulo, v. 59, n. 2-A, p. 165-170, 2001.

AXTHELM, M. K.; KRAKOWKA, S. Experimental old dog encephalitis (ODE) in a gnotobiotic dog. Veterinary Pathology, USA, v. 35, n. 6, p. 527-534, 1998.

BAUMGÄRTNER, W.; BOYCE, R. W.; ALLDINGER, S.; AXTHELM, M. K.; WEISBRODE, S. E.; KRAKOWKA, S.; GAEDKE, K. Metaphyseal bone lesions in young dogs with systemic canine distemper virus infection. Veterinary Microbiology, Amsterdam, v. 44, n. 2-4, p. 201-209, 1995a.

BAUMGÄRTNER, W.; BOYCE, R. W.; WEISBRODE, S. E.; ALLDINGER, S.; AXTHELM, M. K.; KRAKOWKA, S. Histologic and immunocytochemical characterization of canine distemper-associated metaphyseal bone lesions in young dogs following experimental infection. Veterinary Pathology, Washington, v. 32, n. 6, p. 702709, 1995 b.

BEINEKE, A.; PUFF, C.; SEEHUSEN, F.; MAUMGÄRTNER, W. Pathogenesis and immunopathology of systemic and nervous canine distemper. VeterinaryImmunology andImmunopathology, Amsterdam, v. 127, n. 1-2, p. 1-18, 2009.
BLANCOU, J. Dog distemper: imported into Europe from South America? Historia Medicinae Veterinariae, Denmark, v. 29, n. 2, p. 35-41, 2004.

BORBA, T. R.; MANNIGEL, R. C.; FRAPORTI, C. K.; HEADLEY, S. A.; SAITO, T. B. Cinomose: dados epidemiológicos Maringá-PR (1998-2001). Iniciação Científica Cesumar, Maringá, v. 4, n. 1, p. 53-56, 2002.

BRAUND, K. G. Clinical syndromes in veterinary neurology. 2. ed. St. Louis: Mosby, 1994.

CARDOSO, E.; FUKUDA, T.; PEREIRA, J.; SEIXAS, J.; MIRANDA, R.; RODRIGUES, B.; SABACK, T.; ANDRADE, R.; CARDOSO, G.; MARTINEZ, R.; AVENA, J.; MELO, A. Clinical and epidemiological profile of multiple sclerosis in a reference center in the State of Bahia, Brazil. Arquivos de Neuropsiquiatria, São Paulo, v. 64, n. 3B, p. 727-730, 2006.

CASWELL, J. L.; WILLIAMS, K. J. Respiratory system. In. MAXIE. M. G. (Ed.). Jubb, Kennedy \& Palmer's pathology of domestic animals. $5^{\text {th }}$ ed. Philadelphia: Saunders/Elsevier, 2007. v. 2, p. 524-653.

CASTILHO, J. G.; BRANDÃO, P. E.; CARNIELI JUNIOR, P.; OLIVEIRA, R. N.; MACEDO, C. I., PEIXOTO, Z. M. P.; CARRIERI, M. L.; KOTAIT, I. Molecular analysis of the $\mathrm{N}$ gene of canine distemper virus in dogs in Brazil. Arquivo Brasileiro de Medicina Veterinária e Zootecnia, Belo Horizonte, v. 59, n. 3, p. 654-659, 2007.

CLEAVELAND, S.; APPEL, M. G. J.; CHALMERS, W. S. K.; CHILLINGWORTH, C.; KAARE, M.; DYE, C. Serological and demographic evidence for domestic dogs as a source of canine distemper virus infection for Serengeti wildlife. Veterinary Microbiology, Amsterdam, v. 72, n. 3-4, p. 217-227, 2000.

COOK, S. D.; BLUMBERG, B.; DOWLING, P. C.; DEANS, W.; CROSS, R. Multiple sclerosis and canine distemper on Key West, Florida. Lancet, London, v. 329, n. 8547, p. 1426-1427, 1987.

COOK, S. D.; DOWLING, P. C. A possible association between house pets and multiple sclerosis. Lancet, London, v. 1, n. 8019, p. 980-982, 1977.

COOK, S. D.; DOWLING, P. C.; RUSSELL, W. C. Multiple sclerosis and canine distemper. Lancet, London, v. 1, p. 605-606, 1978.

. Multiple sclerosis and canine distemper in Iceland. Lancet, London, v. 313, n. 8112, p. 380-381, 1979.

CORDY, D. R. Canine encephalomyelitis. Cornell Veterinary, New York, v. 32, n. 1, p. 11-28, 1942. 
COURTENAY, O.; QUINNELL, R. J.; CHALMERS, W. S. Contact rates between wild and domestic canids: no evidence of parvovirus or canine distemper virus in crab-eating foxes. Veterinary Microbiology, Amsterdam, v. 81, n. 1, p. 9-19, 2001.

CURI, N. H. A.; ARAÚJO, A. S.; CAMPOS, F. S.; LOBATO, Z. I. P.; GENNARI, S. M.; MARVULO, M. F. V.; SILVA, J. C. R.; TALAMONI, S. A. Wild canids, domestic dogs and their pathogens in Southeast Brazil: disease threats for canid conservation. Biodiversity and Conservation, London, v. 19, n. 12, p. 3513-3524, 2010.

DASZAK, P.; CUNNINGHAM, A. A.; HYATT, A. D. Emerging infectious diseases of wildlife threats to biodiversity and human health. Science, Tóquio, v. 287, n. 5452, p. 443-449, 2000.

DEAN, G.; McLOUGHLIN, H.; BRADY, R.; ADELSTEIN, A. M.; TALLETT-WILLIAMS, J. Multiple sclerosis among immigrants in Greater London. British Medical Journal, London, v. 1, n. 6014, p. 861864, 1976.

DEL PUERTO, H. L.; VASCONCELOS, A. C.; MORO, L.; ALVES, F.; BRAZ, G. F.; MARTINS, A. S. Canine distemper virus detection in asymptomatic and non vaccinated dogs. Pesquisa Veterinária Brasileira, Rio de Janeiro, v. 30, n. 2, p. 132-138, 2010.

DEZENGRINI, R.; WEIBLEN, R.; FLORES, E. F. Soroprevalência das infecções por parvovírus, adenovírus, coronavírus canino e pelo vírus da cinomose em cães de Santa Maria, Rio Grande do Sul, Brasil. Ciência Rural, Santa Maria, v. 37, n. 1, p. 183-189, 2007.

DIAS, R. A.; GARCIA, R. C.; SILVA, D. F.; AMAKU, M.; FEREIRA NETO, J. S.; FERREIRA, F. Estimativa de populações canina e felina domiciliadas em zona urbana do Estado de São Paulo. Revista de Saúde Pública, São Paulo, v. 38, n. 4, p. 565-570, 2004.

DUBIELZIG, R. R. The effect of canine distemper virus on the ameloblastic layer of the developing tooth. Veterinary Pathology, Washington, v. 16, n. 2, p. 268270, 1979.

EK-KOMMONEN, C.; SIHVONEN, L.; PEKKANEN, K.; RIKULA, U.; NUOTIO, L. Outbreak off canine distemper in vaccinated dogs in Finland. Veterinary Records, London, v. 141, n. 15, p. 380-383, 1997.

FAWI, M. T.; TAG EL DIN, M. H.; EL-SANOUSI, S. M. Canine distemper as a predisposing factor for Nocardia asteroides infection in the dog. Veterinary Records, London, v. 88, n. 13, p. 326-328, 1971.

FIGHERA, R. A.; SOUZA, T. M.; SILVA, M. C.; BRUM, J. S.; GRAÇA, D. L.; KOMMERS, G. D.; IRIGOYEN, L. F.; BARROS C. S. L. Causas de morte e razões para eutanásia de cães da Mesorregião do Centro Ocidental Rio-Grandense (1965-2004). Pesquisa Veterinária Brasileira, Rio de Janeiro, v. 28, n. 4, p. 223-230, 2008.

FINKELSZTEJN, A.; CRISTOVAM, R. A.; MOARES, G. S.; LOPES, M. G. S. M.; SILVA, A. V.; GARCIA, M. S.; COLA, C. M. M.; BASTIANI, C. E.; FERREIRA, L. B.; COSTA, A. L.; SCHNEIDER, S. M. B.; FRISON, T. B. Clinical features of multiple sclerosis in the south of Brazil: a partial analysis. Arquivos de Neuropsiquiatria, São Paulo, v. 67, n. 4, p. 1071-1075, 2009.

FINNIE, J. W.; HOOPER, P. T. Polioencephalomalacia in dogs with distemper encephalitis. Australian Veterinary Journal, Brunswick, v. 61, n. 12, p. 407-408, 1984.

FRAGOSO, Y. D.; PERES, M. Prevalence of multiple sclerosis in the city of Santos, SP. Revista Brasileira de Epidemiologia, São Paulo, v. 10, n. 4, p. 479-482, 2007.

GLEDHILL, A. W. Veterinary diseases of medical interest. British Medical Bulletin, London, v. 9, n. 3, p. 237-241, 1953.

GORDON, M. T.; ANDERSON, D. C.; SHARPE, P. T. Canine distemper virus localized in bone cells of patients with Paget's disease. Bone, New York, v. 12, n. 3, p. $195-$ 201, 1991.

GORDON, M. T.; BELL, S. C.; MEE, A. P.; MERCER, S.; CARTER, S. D.; SHARPE, P. T. Prevalence of canine distemper antibodies in the pagetic population. Journal of Medical Virology, New York, v. 40, n. 4, p. 313-317, 1993.

GORHAM, J. R. The epizootiology of distemper. Journal of American Veterinary Medical Association, New York, v. 149, n. 5, p. 610-622, 1966.

GORMAN, N. T.; HABICHT, J.; LACHMANN, P. J. Intracerebral synthesis of antibodies to measles and distemper viruses in patients with subacute sclerosing panencephalitis and multiple sclerosis. Clinical and Experimental Immunology, Oxford, v. 39, n. 1, p. 44-52, 1980.

GOUVEIA, A. M. G.; MAGALHÃES, H. H.; RIBEIRO, A. L. Cinomose canina: ocorrência em animais vacinados e distribuição por faixa etária. Arquivo Brasileiro de Medicina Veterinária e Zootecnia, Belo Horizonte, v. 39, n. 4, p. 539-545, 1987.

GOWTAGE-SEQUEIRA, S.; BANYARD, A. C.; BARRETT, T.; BUCZKOWSKI, H.; FUNK, S. F.; CLEAVELAND, S. Epidemiology, pathology, and genetic analysis of a canine distemper epidemic in Namibia. Journal of Wildlife Diseases, Ames, v. 45, n. 4, p. 1008-1020, 2009. 
GREENE, C. A.; APPEL, M. J. Canine distemper. In: GREENE, C. A. (Ed.). Infectious diseases of the cat and dog. 3. ed. Elsevier/Saunders, St. Louis, Missouri, 2006. p. $25-41$

GRIZ, L.; CALDAS, G.; BANDEIRA, C.; ASSUNÇÃO, V.; BANDEIRA, F. Paget's disease of bone. Arquivo Brasileiro de Endocrinologia e Metabolismo, São Paulo, v. 50, n. 4, p. 814-822, 2006.

GUEDES, I. B.; LIMA, A. S.; ESPINHEIRO, R. F.; MANSSOUR, M. B.; CRUZ, I. P.; DIAS, H. L. T. Occurrence and geographical assessment of canine distemper in the city of Belém, Pará-Brazil. 2010. Available at: <http://www.vin.com/proceedings $>$. Accessed at: 03 dez. 2010.

HASS, R.; JOHANN, J. M.; CAETANO, C. F.; FISCHER, G.; VARGAS, G. D.; VIDOR, T.; HÜBNER, S. O. Níveis de anticorpos contra o vírus da cinomose canina e o parvovírus canino em cães não vacinados e vacinados. Arquivo Brasileiro de Medicina Veterinária e Zootecnia, Belo Horizonte, v. 60, n. 1, p. 270-274, 2008.

HEADLEY, S. A. Astrócitos imunorreativos a GFAP em cães naturalmente infectados pelo vírus da cinomose. 1999. Dissertação (Mestrado em Medicina Veterinária - Área de Concentração Patologia Veterinária) Universidade Federal de Santa Maria, Santa Maria.

HEADLEY, S. A.; AMUDE, A. M.; ALFIERI, A. F.; BRACARENSE, A. P. F. R. L.; ALFIERI, A. A.; SUMMERS, B. A. Molecular detection of canine distemper virus and the immunohistochemical characterization of the neurologic lesions in naturally occurring old dog encephalitis. Journal of Veterinary Diagnostic Investigation, Columbia, v. 21, n. 5, p. 588597, 2009.

HEADLEY, S. A.; GRAÇA, D. L. Canine distemper: epidemiological findings of 250 cases. Brazilian Journal of Veterinary Research and Animal Science, São Paulo, v. 37, n. 2, p. 136-140, 2000.

HEADLEY, S. A.; GRAÇA, D. L.; COSTA, M. M.; VARGAS, A. C. Canine distemper virus infection with secondary Bordetella bronchiseptica pneumonia in dogs. Ciência Rural, Santa Maria, v. 29, n. 4, p. 741-743, 1999.

HEADLEY, S. A.; SAITO, T. B. Simultaneous canine distemper encephalitis and canine parvovirus infection with distemper-associated cardiac necrosis in a pup. Ciência Rural, Santa Maria, v. 33, n. 6, p. 1075-1080, 2003.

HEADLEY, S. A.; SHIROTA, K.; BABA, T.; IKEDA, T.; SUKURA, A. Diagnostic exercise: Tyzzer's disease, distemper, and coccidiosis in a pup. Veterinary Pathology, Washington, v. 46, n. 1, p. 151-154, 2009 b.
HEADLEY, S. A.; SOARES, I. C.; GRAÇA, D. L. Glial fibrillary acidic protein (GFAP)-immunoreactive astrocytes in dogs infected with canine distemper virus. Journal of Comparative Pathology, Edinburg, v. 125, n. 2-3, p. 90-97, 2001.

HEADLEY, S. A.; SUKURA, A. Naturally occurring systemic canine distemper virus infection in a pup. Brazilian Journal of Veterinary Pathology, Minas Gerais, v. 2, n. 2, p. 95-101, 2009.

HIGGINS, R. J.; CHILD, G.; VANDEVELDE, M. Chronic relapsing demyelinating encephalomyelitis associated with persistent spontaneous canine distemper virus infection. Acta Neuropathologica, New York, v. 77, n. 4, p. 441-444, 1989.

HOWELL, D. G. Immunization of the dog. Canadian Veterinary Journal, Ottawa, v. 6, n. 6, p. 127-136, 1965.

HÜBNER, S. A.; PAPPEN, F. G.; RUAS, J. L.; VARGAS, G. D.; FISCHER, G.; VIDOR, T. Exposure of pampas fox (Pseudalopex gymnocercus) and crab-eating fox (Cerdocyon thous) from the Southern region of Brazil to Canine distemper virus (CDV), Canine parvovirus (CPV) and Canine coronavirus (CCoV). Brazilian Archives of Biology and Technology, Curitiba, v. 53, n. 3, p. 593-597, 2010.

INSTITUTO BRASILEIRO DE GEOGRAFIA E ESTATÍSTICA - IBGE. 2011. Availabe at: <http://www. censo2010.ibge.gov.br>. Accessed at: 17 jan. 2012.

JONES, T. C.; HUNT, R. D.; KING, N. W. Veterinary pathology. 6. ed. Baltimore: Williams and Wilkins, 1997.

JOTKOWITZ, S. Multiple sclerosis and exposure to house pets. Journal of the American Medical Association, Chicago, v. 238, n. 8, p. 854, 1977.

KAKALACHEVA, K.; MÜNZ, C.; LÜNEMANN, J. D. Viral triggers of multiple sclerosis. Biochimica et Biophysica Acta: Molecular Basis of Disease, Amsterdam, v. 1812, n. 2, p. 132-40, 2011.

KAPIL, S.; ALLISON, R. W.; JOHNSTON III, L.; MURRAY, B. L.; HOLLAND, S.; MEINKOTH, J.; JOHNSON, B. Canine distemper virus strains circulating among North American dogs. Clinical and Vaccine Immunology, Washington v. 15, n. 4, p. 707-712, 2008.

KHAN, S. A.; BRENNAN, P.; NEWMAN, J.; GRAY, R. E. S.; MCCLOSKEY, E. V.; KANIS, J. A. Paget's disease of bone and unvaccinated dogs. Bone, New York, v. 19, n. 1, p. 47-50, 1996.

KOESTNER, A. Animal model of human disease: subacute sclerosing panencephalitis, multiple sclerosis; animal model: distemper-associated demyelinating encephalomyelitis. American Journal of Pathology, Bethesda, v. 78, n. 2, p. 361-364, 1975. 
KOUTINAS, A. F.; POLIZOPOLOU, Z. S.; BAUMGAERTNER, W.; LEKKAS, S.; KONTOS, V. Relation of clinical signs to pathological changes in 19 cases of canine distemper encephalomyelitis. Journal of Comparative Pathology, Edinburgh, v. 126, n. 1, p. 4756, 2002.

KRAKOWKA, S.; KOESTNER, A. Age-related susceptibility to infection with canine distemper virus in gnotobiotic dogs. Journal of Infectious Diseases, Chicago, v. 134, n. 6, p. 629-632, 1976.

Canine distemper virus and multiple sclerosis. Lancet, London, v. 311, n. 8074, p. 1127-1128, 1978.

KURTZKE, J. F.; PRIESTER, W. A. Dogs, distemper, and multiple sclerosis in the United States. Acta Neurologica Scandinavica, Copenhagen, v. 60, n. 5, p. 312-319, 1979.

LAMB, R. A.; KOLAKOFSKY, D. Paramyxoviridae: the viruses and their replication. In: FIELDS, D. M.; KNIPE, D. M.; HOWLEY, P. M. (Ed.). Fields virology. $4^{\text {th }}$ ed. Phialdephia: Lippincott-Williams \& Wilkins, 2001. v. 1, p. 1305-1443.

LINCOLN, J. A.; HANKIEWICZ, K.; COOK, S. D. Could Epstein-Barr virus or canine distemper virus cause multiple sclerosis? Neurologic Clinics, Philadelphia, v. 26, n. 3, p. 699-715, 2008.

LINCOLN, S. D.; GORHAM, J. R.; DAVIS, W. C.; OTT, R. L. Studies of old dog encephalitis. II. Electron microscopic and immunohistologic findings. Veterinary Pathology, Washington, v. 10, n. 2, p. 124-129, 1973.

LINCOLN, S. D.; GORHAM, J. R.; OTT, R. L.; HEGREBERG, G. A. Etiologic studies of old dog encephalitis. I. Demonstration of canine distemper viral antigen in the brain in two cases. Veterinary Pathology, Washington, v. 8, n. 1, p. 1-8, 1971.

LISIAK, J. A.; VANDEVELDE, M. Polioencephalomalacia associated with canine distemper virus infection. Veterinary Pathology, Washington, v. 16, n. 6 , p. 650-660, 1979.

MACLACHLAN, N. J.; DUBOVI, E. J. Paramyxoviridae. Fenner's veterinary virology. 4. ed. California, San Diego: Academic Press, 2011. p. 299-325.

MARTELLA, V.; ELIA, G.; BUONAVOGLIA, C. Canine distemper virus. Veterinary Clinics of North America: Small Animal Practice, Philadelphia, v. 38, n. 4, p. 787-797, 2008.

MAXIE, M. G.; YOUSSEF, S. Nervous system. In. MAXIE, M. G. (Ed.). Jubb, kennedy \& palmer's pathology of domestic animals. $5^{\text {th }}$ ed. Philadelphia: Saunders/Elsevier, 2007. v. 1, p. 281-457.
McBRIDGE, on ulcers of the cornea in dogs suffering from distemper. British Medical Journal, London, p. 159,1870 .

MCCARTHY, A. J.; SHAW, M. A.; GOODMAN, S. J. Pathogen evolution and disease emergence in carnivores. Proceedings of The Royal Society of London B: Biological Sciences, London, v. 274, n. 1629, p. 3165-3174, 2007.

MEE, A. P.; SHARPE, P. T. Dogs, distemper and Paget's disease. BioEssays, Cambridge, v. 15, n. 12, p. 783-789, 1993.

MEE, A. P.; DIXON, J. A.; HOYLAND, J. A.; SELBY, P. L.; MAWER, E. B. Detection of canine distemper virus in $100 \%$ of Paget's disease samples by in situ-reverse transcriptase-polymerase chain reaction. Bone, New York, v. 23, n. 2, p. 171-175, 1998.

MEE, A. P.; GORDON, M. T.; MAY, C.; BENNETT, D.; ANDERSON, D. C.; SHARPE, P.T. Canine distemper virus transcripts detected in the bone cells of dogs with metaphyseal osteopathy. Bone, New York, v. 14, n. 1, p. 59-67, 1993.

MEGID, J.; SOUZA, V. A. F.; TEIXEIRA, C. R.; CORTEZ, A.; AMORIN, R. L.; HEINEMMAN, M. B.; CAGNINI, D. Q.; RICHTZENHAIN, L. J. Canine distemper virus in a crab-eating fox (Cerdocyon thous) in Brazil: case report and phylogenetic analyses. Journal of Wildlife Diseases, Ames, v. 45, n. 2, p. 527-530, 2009.

MEGID, J.; TEIXEIRA, C. R.; AMORIN, R. L.; CORTEZ, A.; HEINEMANN, M. B.; ANTUNES, J. M. A. P.; COSTA, L. F.; FORNAZARI, F.; CIPRIANO, J. R. B.; CREMASCO, A.; RICHTZENHAIN, L. J. First identification of canine distemper virus in hoary fox (Lycalopex vetulus): pathologic aspects and virus phylogeny. Journal of Wildlife Diseases, Ames, v. 46, n. 1, p. 303-305, 2010.

MELCON, M. O.; GOLD, L.; CARRÁ, A.; CÁCERES, F.; CORREALE, J.; CRISTIANO, E.; FERNÁNDEZ LIGUORI, N.; GARCEA, O.; LUETIC, G.; KREMENCHUTZKY, M. Argentine Patagonia: prevalence and clinical features of multiple sclerosis. Multiple Sclerosis, London, v. 14, n. 5, p. 656-662, 2008.

MELI, M. L.; SIMMLER, P.; CATTORI, V.; FERNANDO MARTIÍNEZ, F.; VARGAS, A.; PALOMARES, F.; LÓPEZ-BAO, J. V. C.; SIMÓN, M. A.; LÓPEZ, G.; LEÓN-VIZCAINO, L.; HOFMANN-LEHMANN, R.; LUTZ, H. Importance of canine distemper virus (CDV) infection in free-ranging Iberian lynxes (Lynx pardinus). Veterinary Microbiology, Amsterdam, v. 146, n. 1-2, p. 132-137, 2010. 
MEYERS, D. L.; ZURBRIGGEN, A.; HANS LUTZ, H.; POSPISCHIL, A. Distemper: not a new disease in lions and tigers. Clinical and Diagnostic Laboratory Immunology, Washington, v. 4, n. 2, p. 180-184, 1997.

MILLAIS, E. The pathogenic microbe of distemper in dogs, and its use for protective inoculation. British Medical Journal, London, v. 1, n. 1528, p. 856-860, 1890.

MILLS, B. G.; SINGER, F. R. Nuclear inclusions in Paget's disease of bone. Science, Tóquio, v. 194, n. 4261, p. 201-202, 1976.

MONNE, I.; FUSARO, A.; VALASTRO, V.; CITTERIO, C.; POZZA, M. D.; OBBER, F.; TREVISIOL, K.; COVA, M.; BENEDICTIS, P.; BREGOLI, M.; CAPUA, I.; CATTOLI, G. A distinct CDV genotype causing a major epidemic in Alpine wildlife. Veterinary Microbiology, Amsterdam, v. 150, n. 1-2, p. 63-69, 2011.

MORETTI, L. A.; SILVA, A. V.; RIBEIRO, M. G.; PAES, A. C.; LANGONI, H. Toxoplasma gondii genotyping in a dog co-infected with distemper virus and ehrlichiosis rickettsia. Revista do Instituto de Medicina Tropical de São Paulo, São Paulo, v. 48, n. 6, p. 359-363, 2006.

MORETTI, L. D.; UENO, T. E.; RIBEIRO, M. G.; AGUIAR, D. M.; PAES, A. C.; PEZERICO, S. B.; SILVA, A. V. Toxoplasmose em cães co-infectados com o vírus da cinomose. Semina: Ciências Agrárias, Londrina, v. 23, n. 1, p. 85-91, 2002.

MYERS, D. L.; ZURBRIGGEN, A.; LUTZ, H.; POSPISCHIL, A. Distemper: not a new disease in lions and tigers. Clinical and Diagnostic Laboratory Immunology, Washington, v. 4, n. 2, p. 180-184, 1997.

NAKAGAWA, T. L. D. R.; BRACARENSE, A. P. F. R.; REIS, A. C. A.; YAMAMURA, M. Y.; HEADLEY, S. A. Giant kidney worm (Dioctophyma renale) infections in dogs from Northern Paraná, Brazil. Veterinary Parasitology, Amsterdam, v. 145, n. 3-4, p. 366-370, 2007.

NAVA, A. F. D.; CULLEN JUNIOR, L.; SANA, D. A.; NARDI, M. S.; RAMOS FILHO, J. D.; LIMA, T. F.; ABREU, K. A.; FERREIRA, F. First evidence of canine distemper in Brazilian free-ranging felids. EcoHealth, New York, v. 5, n. 4, p. 513-518, 2008.

NEGRÃO, F. J.; WOSIACKI, S. H.; ALFIERI, A. A.; ALFIERI, A. F. Perfil de restrição de um fragmento do gene da hemaglutinina amplificado pela RT-PCR a partir de estirpes vacinais e selvagens do vírus da cinomose canina. Arquivo Brasileiro de Medicina Veterinária e Zootecnia, Belo Horizonte, v. 58, n. 6, p. 1099-1106, 2006.
O'DRISCOLL, J. B.; BUCKER, H. M.; JEACOCK, J.; ANDERSON, D. C. Dogs, distemper and osteitis deformans: a further epidemiological study. Journal of Bone and Mineral Research, Washington, v. 11, n. 2, p. 209-216, 1990.

O'DRISCOLL, J. B.; ANDERSON, D. C. Past pets and Paget's disease. Lancet, London, v. 2, n. 8461, p. 919921, 1985.

OSTERHAUS, A. D. M. E.; SWART, R. L.; VOS, H. W.; ROSS, P. S.; KENTER, M. J. H.; BARRETT, T. Morbillivirus infections of aquatic mammals: newly identified members of the genus. Veterinary Microbiology, Amsterdam, v. 44, n. 2-4, p. 219-227, 1995.

PARDO, I. D.; JOHNSON, G. C.; KLEIBOEKER, S. B. Phylogenetic characterization of canine distemper viruses detected in naturally infected dogs in North America. Journal of Clinical Microbiology, Washington, v. 43, n. 10, p. 5009-5017, 2005.

PERRONE, D.; BENDER, S.; NIEWIESK, S. A. Comparison of the immune responses of dogs exposed to canine distemper virus (CDV) - differences between vaccinated and wild-type virus exposed dogs. Canadian Journal of Veterinary Research, Ottawa, v. 74, n. 3, p. 214-217, 2010.

PHILIPPA， J.; FOURNIER-CHAMBRILLON， C.; FOURNIER, P.; SCHAFTENAAR, W.; BILDT, M.; HERWEIJNEN， R.; KUIKEN， T.; LIABEUF， M.; DITCHARRY, S.; JOUBERT, L.; BEGNIER, M.; OSTERHAUS, A. Serologic survey for selected viral pathogens in free-ranging endangered European mink (Mustela lutreola) and other mustelids from southwestern France. Journal of Wildlife Diseases, Ames, v. 44, n. 4, p. 791-801, 2008.

QUINN, P. J.; MARKEY, B. P.; CARTER, M. E.; DONNELLY, M. J.; LEONARD, F. C. Paramyxoviridae. Veterinary microbiology and microbial disease. Ames, Iowa: Blackwell Sciences Ltd. 2004. p. 381-389.

RALSTON, S. H.; AFZAL, M. A.; HELFRICH, M. H.; FRASER, W. D.; GALLAGHER, J. A.; MEE, A.; RIMA, B. Multicenter blinded analysis of RT-PCR detection methods for paramyxoviruses in relation to Paget's disease of bone. Journal of Bone and Mineral Research, Washington, v. 22, n. 4, p. 569-577, 2007.

RALSTON, S. H.; DIGIOVINE, F. S.; GALLACHER, S. J.; BOYLE, I. T.; DUFF, G. W. Failure to detect paramyxovirus sequences in Paget's disease of bone using the polymerase chain reaction. Journal of Bone and Mineral Research, Washington, v. 6, n. 11, p. 1243-1248, 1991. 
READ, D.; NASSIM, D.; SMITH, P.; PATTERSON, C.; WARLOW, C. Multiple sclerosis and dog ownership. A case-control investigation. Journal of the Neurological Sciences, Amsterdam, v. 55, n. 3, p. 359-367, 1982.

REGO, A. A. M. S.; MATUSHIMA, E. R.; PINTO, C. M.; BIASIA, I. Distemper in Brazilian wild canidae and mustelidae: case report. Brazilian Journal of Veterinary Research and Animal Science, São Paulo, v. 34, n. 3, p. 256-258, 1997.

ROHOWSKY-KOCHAN, C.; DOWLING, P. C.; COOK, S. D. Canine distemper virus-specific antibodies in multiple sclerosis. Neurology, Minneapolis, v. 45, n. 8, p. 1554-1560, 1995.

ROSCOE, D. E. Epizootiology of canine distemper in New Jersey raccoons. Journal of Wildlife Diseases, Ames, v. 29, n. 3, p. 390-395, 1993.

SERAFIN, C. A.; ROSA, G. A.; GUIMARÃES, A. M. S.; UTIME, R. A.; BIONDO, A. W. Quem mora em prédios tem mais ou menos cães e gatos? 2011. Available at: <www.crmv-pr.org.br>. Accessed at: 14 fev. 2011.

SI, W.; ZHOU, S.; WANG, Z.; CUI, S. J. A multiplex reverse transcription-nested polymerase chain reaction for detection and differentiation of wild-type and vaccine strains of canine distemper virus. Virology Journal, v. 7, n. 86, p.1-6, 2010.

SILVA, M. C.; FIGHERA, R. A.; BRUM, J. S.; GRAÇA, D. L.; KOMMERS, G. D.; IRIGOYEN, L. F.; BARROS, C .S. L. Aspectos clinicopatológicos de 620 casos neurológicos de cinomose em cães: Clinicopathological features in 620 neurological cases of canine distemper. Pesquisa Veterinária Brasileira, Rio de Janeiro, v. 27, n. 5, p. 215-220, 2007.

SILVA, M. C.; FIGHERA, R. A.; MAZZANTI, A.; BRUM, J. S.; PIEREZAN, F.; BARROS, C. S. L. Neuropatologia da cinomose canina: 70 casos (20052008). Pesquisa Veterinária Brasileira, Rio de Janeiro, v. 29 , n. 8 , p. 643-652, 2009.

SIMON-MARTÍNEZ, J.; ULLOA-ARVIZU, R.; SORIANO, V. E.; FAJARDO, R. Identification of a genetic variant of canine distemper virus from clinical cases in two vaccinated dogs in Mexico. Veterinary Journal, London, v. 175, n. 3, p. 423-426, 2008.

SONNE, L.; OLIVEIRA, E. C.; PESCADOR, C. A.; SANTOS, A. S.; PAVARINI, S. P.; CARISSIMI, A. S.; DREIMEIER, D. Achados patológicos e imunohistoquímicos em cães infectados naturalmente pelo vírus da cinomose canina. Pesquisa Veterinária Brasileira, Rio de Janeiro, v. 29, n. 2, p. 143-149, 2009.
SUMMERS, B. A.; APPEL, M. J. Aspects of canine distemper virus and measles virus encephalomyelitis. Neuropathology and Applied Neurobiology, Oxford, v. 20, n. 6, p. 525-534, 1994.

SUMMERS, B. A.; GREISEN, H. A.; APPEL, M. J. Canine distemper encephalomyelitis: variation with virus strain. Journal of Comparative Pathology, Edinburgh, v. 94, n. 1, p. 65-75, 1984.

SUMMERS, B. A.; CUMMINGS, J. F.; DE LAHUNTA, A. Veterinary neuropathology. St. Louis: Mosby, 1994. $527 \mathrm{p}$.

TAMURA, K.; DUDLEY, J.; NEI, M.; KUMAR, S. MEGA 4: molecular evolutionary genetics analysis (MEGA) software version 4.0. Molecular Biology and Evolution, Chicago, v. 24, n. 8, p. 1596-1599, 2007.

TIPOLD, A.; VANDEVELDE, M.; JAGGY, A. Neurologic manifestations of canine distemper virus infection. Journal of Small Animal Practice, Oxford, v. 33, p. 466-470, 1992.

VANDEVELDE, M.; FANKHAUSER, R.; KRISTENSEN, F. Immunoglobulins in demyelinating lesions in canine distemper encephalitis. An immunohistological study. Acta Neuropathologica, New York, v. 54, n. 1, p. 31-41, 1981.

VANDEVELDE, M.; KRISTENSEN, B.; BRAUND, K. G.; GREENE, C. E.; SWANGO, L. J.; HOERLEIN, B. F. Chronic canine distemper virus encephalitis in mature dogs. Veterinary Pathology, Washington, v. 17, n. 1, p. 17-28, 1980.

VANDEVELDE, M.; ZURBRIGGEN, A. Demyelination in canine distemper virus infection: a review. Acta Neuropathologica, New York, v. 109, n. 1, p. 56-68, 2005.

The neurobiology of canine distemper virus infection. Veterinary Microbiology, Amsterdam, v. 44, n. 2-4, p. 271-280, 1995.

WIKIPEDIA. List of countries by GDP (nominal). 2011. Disponível em: <http://www.wikepedia.org>. Acesso em: 18 fev. 2011.

WOMA, T. Y.; VAN VUUREN, M.; BOSMAN, A-M.; QUAN, M.; OOSTHUIZEN, M. Phylogenetic analysis of the haemagglutinin gene of current wild-type canine distemper viruses from South Africa: lineage Africa. Veterinary Microbiology, Amsterdam, v. 143, n. 2-4, p. 126-132, 2010. 